Journal of the

HYDRAULICS DIVISION

Proceedings of the American Society of Civil Engineers

\title{
HYDRODYNAMIC ANALYSIS FOR HIGH-HEAD LEAF GATES ${ }^{a}$
}

By Eduard Naudascher, 1 M. ASCE, Helmut E. Kobus, ${ }^{2}$ and Ragam Pandu R. Rao ${ }^{3}$

\section{SYNOPSIS}

A one-dimensional analysis of the flow controlled by a high-head gate and of the hydraulic downpull acting on it is presented. The most significant of the flow parameters involved, and a nondimensional term $\bar{\kappa}$ (Kappa) which describes in a complete manner the effect of boundary geometry on the downpull, are evaluated from systematic air-tunnel experiments. The analysis is used as a basis for the presentation of generalized design information. Although it is applied only to the leaf-type gate in this paper, the analysis should prove adaptable also to other types of closure devices for high heads.

\footnotetext{
Note.-Discussion open until October 1,1964 . Separate discussions should be submitted for the individual papers in this symposium. To extend the closing date one month, a written request must be filed with the Executive Secretary, ASCE. This paper is part of the copyrighted Journal of the Hydraulics Division, Proceedings of the American Society of Civil Engineers, Vol. 90, No. HY3, May, 1964.

a This paper is one of three originally presented as part of the Symposium on "Hytraulic Forces on High-Head Gates," on May 14,1963, as part of ASCE Water Resources Ingineering Conference at Milwaukee, Wis.

1 Assoc. Prof. of Mechanics and Hydraulics, Univ. of Iowa, and Research Engr., Inst. If Hydr. Research, Iowa City, Iowa.

2 Research Assoc., Inst. of Hydr. Research, Iowa City, Iowa.

3 Research Asst., Inst. of Hydr. Research, Iowa City, Iowa, on leave from Andhra Jniv., Waltair, India.
} 


\section{INTRODUCTION}

Leaf gates are among the most widely used high-head gates for flow regulation or emergency closure of large outlets and conduits because of the many advantages they offer in construction and maintenance. Two arrangements may be distinguished: the leaf gate can be operated either in a bonnet or gate well located within a conduit transition [tunnel-type gate, Fig. 1(a)] or on the upstream face of a dam or an intake structure [face-type gate, Figs.1(b), 1(c), and $1(\mathrm{~d})$ ]. In either case, the pressure along the bottom surface of the gate is reduced during operation as a result of the high efflux velocities, whereas the pressure on the upper portion of the gate is only slightly changed from static

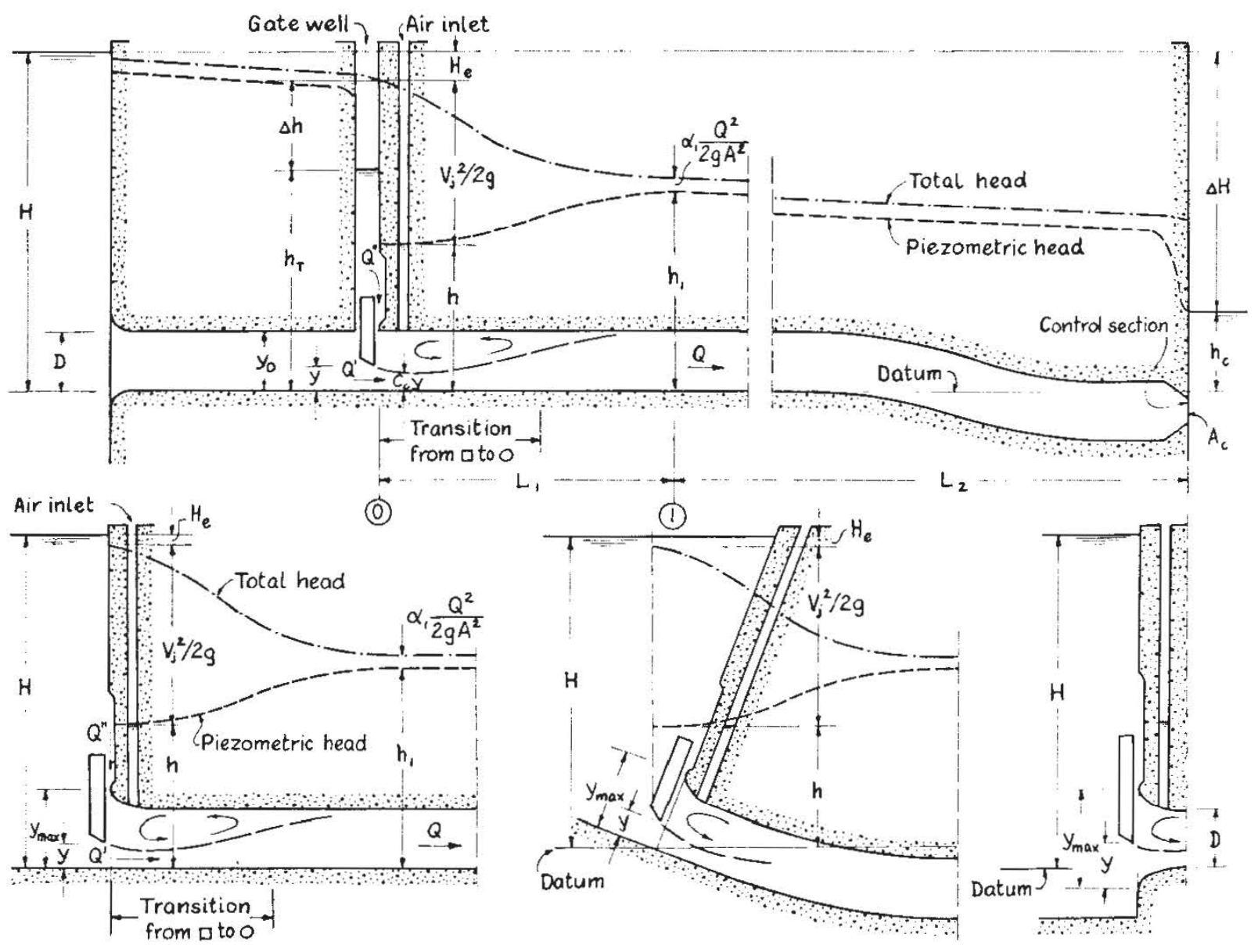

FIG. 1.-SCHEMATIC REPRESENTA TION OF TYPICAL LEAF-GATE ARRANGEMENTS UNDER SUBMERGED FLOW CONDITIONS

conditions. The resulting pressure difference induces an unbalanced downward force which often exceeds the dead weight of the gate considerably. $\mathrm{Be}-$ cause the magnitude of this force, commonly known as the hydraulic downpull, affects the dimensioning of the hoist mechanism and, hence, the safety of the entire project, its prediction has been, and still is, of major concern to hydraulic engineers.

Although extensive downpull studies have been conducted in the past (Appendix II-A), there is no satisfactory method available for adapting these findings to new projects in more than a qualitative manner, and specific model 
tests are still indispensable. The difficulty in applying previous experimental work lies in the fact that not only the boundary geometry, but also the flow conditions under which the gate is operated, vary from project to project. Based on initial analytical work, (A16 and A18), 4 and continued investigations conducted at the Iowa Institute of Hydraulic Research, the present paper is intended to provide a framework for the generalization of experimental downpull data by analyzing separately the effects of geometry and flow conditions on the downpull.

The main portion of the downpull results from the difference between the pressure forces acting on the top and bottom surfaces of the gate, the residual portion acts on the seals and other protrusions of the gate. Essential for the downpull analysis, hence, is the prediction of the pressure forces effective on the top and on the bottom of the gate, each of which can be expressed by the ratio $\bar{\kappa}$ of the respective mean piezometric head to a reference velocity head. The significance of the $\bar{\kappa}$-terms so obtained is their independence of the absolute magnitude of the flow velocities. Once determined they can be used in combination with any flow condition so long as the boundary geometry is similar, provided the Reynolds number is sufficiently high。 This condition is usually satisfied for high-head gates. The downpull analysis is thus reduced to the evaluation of the $\bar{\kappa}$-terms for a particular geometry configuration and the determination of the reference velocity head for a particular flow condition.

The latter part of the problem is approached semi-empirically. By the one-dimensional method of analysis an equation is derived expressing the rate of flow past the gate as a function of the gate opening and width, the total head over the conduit inlet, and the conditions of control in the conduit downstream from the gate. Such effects upon the rate of flow as stem from the flow contraction at the gate, the entrance head loss, the shape and the surface roughness of the transition downstream from the gate, or the fact that water may also be released through a recess of the concrete face opposite to the top seal, are considered with the aid of empirical coefficients. Except for the contraction coefficient, they prove to be of relatively small importance in the evaluation of the rate of flow, so that good results are obtained even with the coefficients only approximated.

Information as to the $\bar{\kappa}$-terms and the empirical coefficients previously mentioned (all functions of the gate and conduit geometry) has necessarily to be derived from experiments. The main results from air-tunnel tests, conducted at the Iowa Instilute of Hydraulic Research on an idealized twodimensional model of a high-head gate, are presented as a first contribution toward a generalized presentation of such data. The studies are being continued. The idealization was adopted in order to distinguish clearly the relative influence of such primary boundary variables as the inclination of the bottom surface of the gate and the rounding of its upstream edge, the possible projection of the gate lip, the gate thickness relative to the conduit height, and the gate opening. In addition, it permits certain conclusions relative to the susceptibility of a given geometry of the gate lip to cavitation and vibration. The paper concludes with a comprehensive bibliography on topics related to the hydraulics of high-head gates.

Notation.-Letter symbols adopted for use in this paper are defined where they first appear and listed alphabetically in Appendix I. - Notation.

\footnotetext{
${ }^{4}$ Numerals in parentheses refer to corresponding items listed in Appendix II.Bibliography.
} 


\section{FLOW ANALYSIS}

Two states of flow may be distinguished-the free-surface case, in which the jet of water issues from the gate with a free surface, and the submerged case, in which the jet is drowned by a standing eddy. The transition from one state of flow to the other occurs as a hydraulic jump approaches or withdraws from the gate. The corresponding intermittent state of partially submerged flow is limited to an extremely small range of gate openings and has therefore been omitted in the following analysis.

Submerged Flow.-For most installations of high-head gates the state of submerged flow is predominant during their operation. The line of total head and the line of piezometric head for both tunnel-type and face-type gates under submerged conditions are illustrated in Fig. 1. If the head losses involved between reservoir and gate section are summarized by means of one over-all entrance loss $\mathrm{He}$ in the form

$$
\mathrm{H}_{\mathrm{e}}=\mathrm{C}_{\mathrm{e}} \frac{1}{2 \mathrm{~g}}\left(\frac{\mathrm{Q}}{\mathrm{A}}\right)^{2} \ldots \ldots \ldots \ldots \ldots
$$

then the rate of flow $Q^{\prime}$ released by the gate is obtained from the onedimensional energy relationship as

$$
Q^{\prime}=a^{\prime} A \sqrt{2 g\left(H-H_{e}-h\right)} \ldots \ldots \ldots \ldots
$$

in which

$$
a^{\prime}=\frac{{ }_{c}{ }^{y b}}{A} \ldots \ldots \ldots \ldots \ldots \ldots
$$

is the ratio of the cross-sectional area $\mathrm{C}_{\mathrm{c}} \mathrm{y} \mathrm{b}$ of the fully contracted jet to the area $\mathrm{A}$ of the conduit section, and $\mathrm{H}$ and $\mathrm{h}$ are the total head in the reservoir and the piezometric head at any point in the contracted jet, respectively, both referred to a common datum. The velocity distribution in the contracted section of the jet is assumed to be uniform.

Most of the recent high-headoutlet works provide a recess in the concrete face opposite to the top seal of the gate through which water is released during gate operation at the rate

$$
Q^{\prime \prime}=C A_{2} \sqrt{2 g\left(H-H_{e}-h\right)} \ldots \ldots \ldots
$$

if it is assumed that the jet, issuing from the gap between the downstream face of the gate and the downstream wall of the gate chamber, has a cross-sectional area $\mathrm{A} 2$ and a piezometric head $\mathrm{h}$ at its fully contracted section. The symbol $\mathrm{C}$ denotes a discharge coefficient.

The total rate of flow past the gate can now be written

$$
\mathrm{Q}=\mathrm{Q}^{\prime}+\mathrm{Q}^{n}=\mathrm{a} A \sqrt{2 \mathrm{~g}\left(\mathrm{H}-\mathrm{H}_{\mathrm{e}}-\mathrm{h}\right)} \ldots \ldots \ldots
$$


with

$$
a=\frac{\left(C_{c} y b+C A_{2}\right)}{A} \ldots \ldots \ldots \ldots
$$

The impulse-momentum relationship, if integrated in the direction of the conduit axis over the reach between section $(0)$ of the contracted jet and section (1), takes the form

$$
F_{0}-F_{1}-F_{2}-F_{S}=\rho \beta_{1} \frac{Q^{2}}{A}-\rho \frac{\left(Q^{\prime}\right)^{2}}{a^{\prime} A} \ldots \ldots \ldots
$$

in which force due to pressure in section (0) is

$$
\mathrm{F}_{0}=\gamma\left(\frac{\mathrm{h}-\mathrm{y}_{\max }}{2}\right) \text { b } \mathrm{y}_{\max } \ldots \ldots \ldots
$$

the force due to pressure in section (1) is

$$
F_{1}=\gamma\left(\frac{h_{1}-D}{2}\right)
$$

and force due to pressure on the vertical projection of the transition walls between sections (0) and (1) is

$$
F_{2}=F_{0}-\gamma\left(\frac{h-D}{2}\right) A+\gamma\left(h_{1}-h\right)\left(b_{\max }-A\right) \frac{\zeta}{2} \ldots .(8 c)
$$

In addition $\zeta$ refers to the factor compensating for the assumption of hydrostatic pressure distribution in the transition between sections (0) and (1), (for long transitions $\zeta \rightarrow 1$, for short ones $\zeta-0$ ), and the factor compensating for the use of the mean velocity in section (1) is defined by

$$
\beta_{1}=\left(\frac{1}{A}\right) \int_{A}\left(\frac{v_{1}}{v_{1}}\right)^{2} d A \ldots \ldots \ldots \ldots
$$

The momentum of the flow $Q^{n}$ is not included, because it is directed perpendicular to the axis of the conduit. The component $F_{S}$ of the force due to boundary shear in the reach between section (0) and (1) acting in the direction of the conduit axis can be approximated, when using the Darcy-Weisbach resistance formula, as

$$
\mathrm{F}_{\mathrm{s}}=\gamma \mathrm{A}_{\mathrm{m}}\left(\mathrm{h}_{\mathrm{f}}\right)_{\mathrm{m}}=\gamma \mathrm{A}_{\mathrm{m}} \mathrm{f} \frac{\mathrm{L}_{1}}{4 \mathrm{R}_{\mathrm{m}}} \frac{\mathrm{V}_{\mathrm{m}}^{2}}{2 \mathrm{~g}} \ldots \ldots \ldots
$$


in which $\mathrm{Am}_{\mathrm{m}}$ is the average cross-sectional area of the flow passage and $\mathrm{V}_{\mathrm{m}}$ the average mean velocity. If the average effective hydraulic radius $R_{m}$ in the reach between sections $(0)$ and (1) is approximated by

$$
R_{m}=\frac{A\left(1+a^{\prime}\right)}{b+2 y+\pi D}=\frac{D}{4} \frac{1+a^{\prime}}{N} \ldots \ldots \ldots
$$

$\mathrm{N}$ being a parameter for the average wetted perimeter,

$$
N=\frac{(\pi D+b+2 y)}{\pi D} \ldots \ldots \ldots \ldots(12
$$

and Eqs. 2 and 5 are substituted, $F_{S}$ becomes

$$
F_{S}=f \frac{L_{1}}{D} \frac{N}{8}(1+a)^{2} \gamma A\left(H-H_{e}-h\right) \ldots \ldots(13
$$

and $\mathrm{Eq} .7$ results in

$$
\mathrm{H}-\mathrm{H}_{\mathrm{e}}-\mathrm{h}=\frac{\mathrm{H}-\mathrm{H}_{\mathrm{e}}-\mathrm{h}_{1}}{1+\left[\frac{\left(\beta_{1} \mathrm{a}^{2}-\mathrm{a}^{\prime}\right) 2}{\mathrm{~K}}\right]+(1+\mathrm{a})^{2} \mathrm{f}\left(\frac{\mathrm{L}_{1}}{\mathrm{D}}\right) \frac{\mathrm{N}}{\mathrm{K}}}
$$

in which $\mathrm{K}$ combines the terms

$$
\mathrm{K}=1+\frac{\zeta}{2}\left(\frac{\mathrm{b} \mathrm{y}_{\max }}{\mathrm{A}}-1\right) \ldots \ldots \ldots \ldots \ldots
$$

The piezometric head h1 in section (1) follows from the one-dimensional energy relationship applied to the sections (1) and (c), the latter being the section of downstream control generally located at the conduit outlet [Fig. 1(a)],

$$
\mathrm{h}_{1}-\mathrm{h}_{\mathrm{c}}=\frac{\mathrm{Q}^{2}}{2 \mathrm{~g}}\left[\frac{\alpha_{\mathrm{c}}}{\mathrm{A}_{\mathrm{c}}^{2}}-\frac{\alpha_{1}}{\mathrm{~A}^{2}}+\mathrm{f} \frac{\mathrm{L}_{2}}{\mathrm{D \textrm {A } ^ { 2 }}}+\mathrm{\Sigma} \frac{\mathrm{C}_{\mathrm{L}}}{\mathrm{A}^{2}}\right] \ldots \ldots(16)
$$

The last two terms to the right of Eq. 16 represent the surface resistance and the sum of local head losses in the reach between sections (1) and (c), and

$$
\alpha=\frac{1}{\mathrm{~A}} \int_{\mathrm{A}}\left(\frac{\mathrm{v}}{\mathrm{V}}\right)^{3} \mathrm{dA}
$$

is a factor compensating for the use of the mean velocity.

For the gate completely withdrawn, the energy equation becomes 


$$
H-h_{c}=\Delta H=\frac{Q_{\max }^{2}}{2 g}\left[\frac{C_{e}}{A^{2}}+\frac{\alpha_{c}}{A_{c}^{2}}+f \frac{L_{1}+L_{2}}{D A^{2}}+\Sigma \frac{C_{L}}{A^{2}}\right] \ldots(
$$

if the average hydraulic radius in the reach between sections (0) and (1) is approximated by $\mathrm{D} / 4$ in this case. Introducing the ratio of the rate of flow $\mathrm{Q}_{\max }$ at the maximum gate opening to the theoretical rate of flow for zero head loss

$$
\mathrm{C}_{0}=\frac{\mathrm{Q}_{\max }}{\mathrm{A} \sqrt{2 \mathrm{~g} \Delta \mathrm{H}}} \ldots \ldots \ldots \ldots \ldots
$$

which is an important design characteristic for any specific project, and substituting Eq. 5 into Eqs. 16 and 13, yields

$$
\mathrm{h}_{1}-\mathrm{h}_{\mathrm{c}}=\mathrm{a}^{2}\left[\frac{1}{\mathrm{C}_{0}^{2}}-\alpha_{1}-\mathrm{C}_{\mathrm{e}}-\frac{\mathrm{f} \mathrm{L}_{1}}{\mathrm{D}}\right]\left(\mathrm{H}-\mathrm{H}_{\mathrm{e}}-\mathrm{h}\right) \ldots(20)
$$

It becomes apparent from this equation that the total head loss downstream from section (1) is taken into account by $\mathrm{C}_{0}$.

With reference to Fig. 1 and through application of Eqs. 1, 14, and 20, the velocity head in the contracted jet under the gate is expressed as

$$
\frac{\mathrm{v}_{\mathrm{j}}^{2}}{2 \mathrm{~g}}=\mathrm{H}-\mathrm{H}_{\mathrm{e}}-\mathrm{h}=\mathrm{C}_{\mathrm{d}}^{2} \Delta \mathrm{H} \ldots \ldots \ldots \ldots(21)
$$

in which

$$
C_{d}=\frac{1}{\sqrt{1+a^{2}\left[\left(\frac{2 \beta_{1}}{K}\right)+\left(\frac{1}{C_{0}^{2}}\right)-\alpha_{1}\right]-\left[\frac{2 a^{\prime}}{K}\right]-\left[a^{2}-(1+a)^{2} \frac{N}{8 K}\right] \frac{f L_{1}}{D}}}
$$

may be defined as a discharge coefficient since

$$
\mathrm{C}_{\mathrm{d}}=\frac{\mathrm{Q}}{(\mathrm{a} \mathrm{A} \sqrt{2 \mathrm{~g} \Delta \mathrm{H})}} \cdots \ldots \ldots \ldots \ldots(23)
$$

With the aid of Eq. 19, the following significant flow characteristics are obtained: 


$$
\begin{aligned}
& \frac{\mathrm{Q}}{\mathrm{Q}_{\max }}=\frac{\mathrm{a} \mathrm{C}_{\mathrm{d}}}{\mathrm{C}_{0}} \ldots \ldots \ldots \ldots \ldots \\
& \frac{\mathrm{Q}^{\prime}}{\mathrm{Q}_{\max }}=\frac{\mathrm{a}^{\prime} \mathrm{C}_{\mathrm{d}}}{\mathrm{C}_{0}} \ldots \ldots \ldots \ldots \ldots \ldots
\end{aligned}
$$

and

$$
\frac{Q^{n}}{Q_{\max }}=\frac{\left(\mathrm{a}-\mathrm{a}^{\prime}\right) \mathrm{C}_{\mathrm{d}}}{\mathrm{C}_{0}}=\left(\frac{\mathrm{C} \mathrm{A}_{2}}{\mathrm{~A}}\right) \frac{\mathrm{C}_{\mathrm{d}}}{\mathrm{C}_{0}} \ldots \ldots \ldots(24 \mathrm{c})
$$

Free-Surface Flow. - If a jet with free surface issues from the gate, air will become entrained in the water and ventilation through an air inlet must be provided if cavitation and vibration are to be avoided. The piezometric head in the contracted section of the jet will then be

$$
\mathrm{h}^{*}=\mathrm{c}_{\mathrm{c}} \mathrm{y}+\frac{\Delta \mathrm{p}}{\gamma} \ldots \ldots \ldots \ldots \ldots \ldots
$$

in which $\Delta \mathrm{p}$ is the difference between the pressure of the air downstream from the gate and the atmospheric pressure at the reservoir $(\Delta p \leq 0)$, which depends on the amount of air entrained by the jet and the dimensioning of the air inlet and can be determined with the aid of the references in Appendix II-D. The rate of flow under the gate becomes, for the state of free-surface flow,

$$
\mathrm{Q}^{\prime}=\mathrm{C}_{\mathrm{c}} \mathrm{yb} \sqrt{2 \mathrm{~g}\left(\mathrm{H}-\mathrm{H}_{\mathrm{e}}-\mathrm{h}^{*}\right)} \ldots \ldots \ldots
$$

and the discharge coefficient $C_{d}$, which was defined as $Q /(a A \sqrt{2 g \Delta H})$ or $\mathrm{V}_{\mathrm{j}} / \sqrt{2 \mathrm{~g} \Delta \mathrm{H}}$, becomes

$$
c_{d}=\sqrt{\frac{H}{\Delta H}} \sqrt{\frac{1-\frac{h^{*}}{H}}{1+a^{2} c_{e}}} \ldots \ldots \ldots
$$

using for simplicity $\mathrm{Q} / \mathrm{a}=\mathrm{Q}^{\prime} / \mathrm{a}^{\prime}$, a relationship which applies only approximately to free-surface flow unless $h^{*}=y_{2}+\Delta p / \gamma$.

If $\mathrm{y}_{2}$ denotes the vertical distance from the datum to the fully contracted section of the jet issuing from the gate chamber, the rate of flow $Q^{n}$ can be written

$$
Q^{n}=C A_{2} \sqrt{2 g\left(H-H_{e}-y_{2}-\frac{\Delta p}{\gamma}\right)} \ldots \ldots \ldots \text { (28) }
$$


provided that the vapor pressure is not reached at any point of the flow passage. [The limitations imposed by this condition have been previously examined (A16, p. 430.)]

In a more significant form, the rates of flow can be expressed as

$$
\frac{Q^{\prime}}{Q_{\max }}=\frac{a^{\prime}}{C_{0} \sqrt{\frac{\Delta H}{H}}} \sqrt{\frac{1-h^{*}}{H+a^{2} C_{e}}} \ldots \ldots \ldots
$$

and

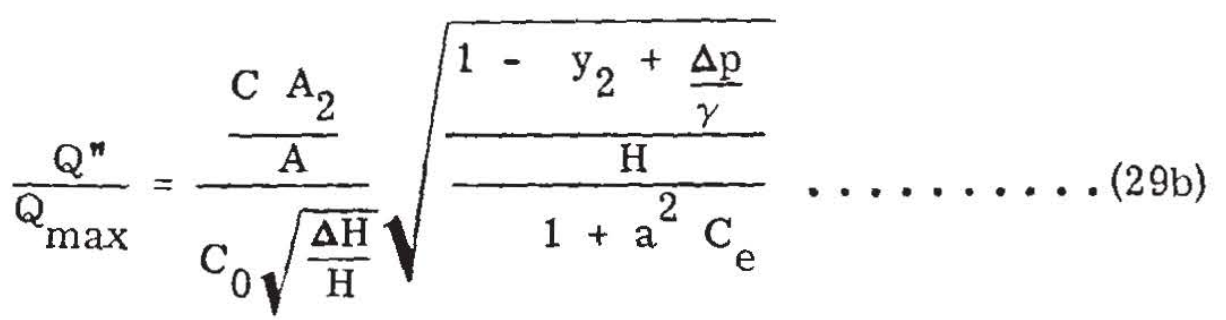

Analysis.-The derived equations apply without difference to tunnel-type and face-type gates. As proved previously (A16), the equations may also be applied to the special cases of face-type gates represented in Fig. 1 (c) and 1 (d), if the datum is chosen as indicated.

The functional relationship of the most significant flow parameters, $C_{d}$ and $Q / Q_{\max }$, for the free and the submerged state of flow, is illustrated by Figs. 2, 4, and 5. (The conditions for the curves of Fig. 2 are $N=2, A_{2}=f$ $=h^{*}=0, \alpha_{1}=\beta_{1}=K=1$. For Fig. $4 \mathrm{~N}=2, A_{2}=f=0, \alpha_{1}=f_{1}=K=1$.) The transition from one state of flow to the other is defined in Fig. 2 by the intersection of the curves which are pertinent to the respective flows. The condition that the jet velocity $V_{j}$ can never exceed the value corresponding to free efflux determines which of the two pertinent curves applies for a particular gate opening. It is interesting to note in this regard that for $\Delta \mathrm{H} / \mathrm{H} \ll 1.0$ and $\mathrm{C}_{0}$ close to unity the free efflux is either physically impossible or limited to intermediate gate openings. With $\Delta \mathrm{H} / \mathrm{H}$ being generally greater than unity, the free efflux is restricted to small gate openings within a range which becomes narrower with decreasing $\mathrm{C}_{0}$.

Part of the complexity of the flow analysis stems from the compensation for the use of mean velocities and hydrostatic pressure distributions and from the consideration of boundary resistance by appropriate parameters. The effect of the respective parameters $\alpha_{1}, \beta_{1}, K$, and $\mathrm{fL}_{1} / \mathrm{D}$ on the rate of flow is illustrated in Figs. 3(b), 3(c), and 3(d) (for extreme departures from the ideal condition $\alpha_{1}=\xi_{1}=\mathrm{K}=1.0$ and $\left.\mathrm{f}=0\right)$. As is apparent from these graphs, the rate of flow becomes more effected by these quantities as $\mathrm{C}_{0}$ is increased. It should be noted that $\alpha_{1}$ and $\beta_{1}$ are functions of $L_{1}$ and of $a^{\prime}$. The percentage increase of $\mathrm{C}_{\mathrm{d}}$ according to the dotted line in Fig. 3(b) could actually never 

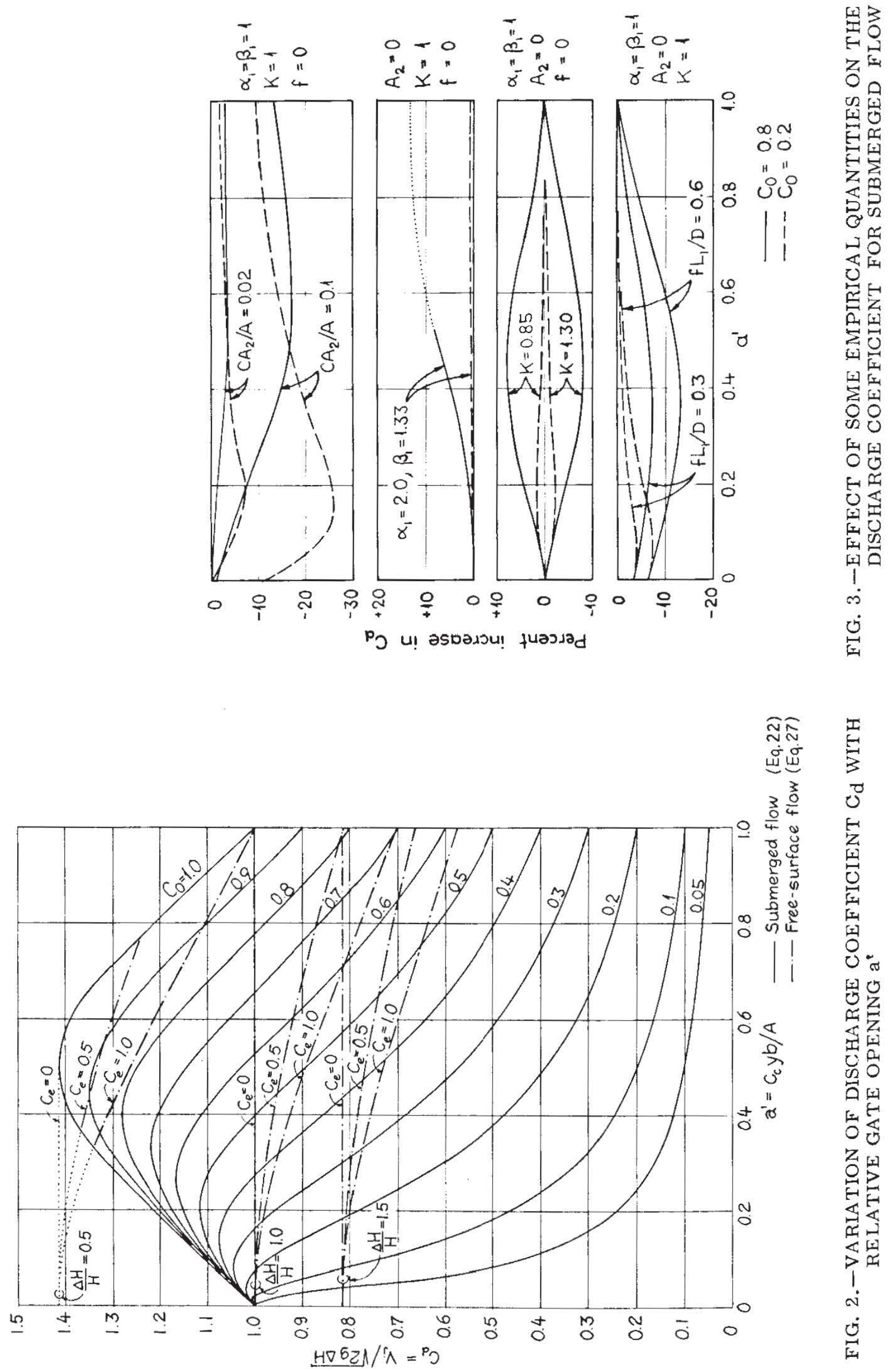


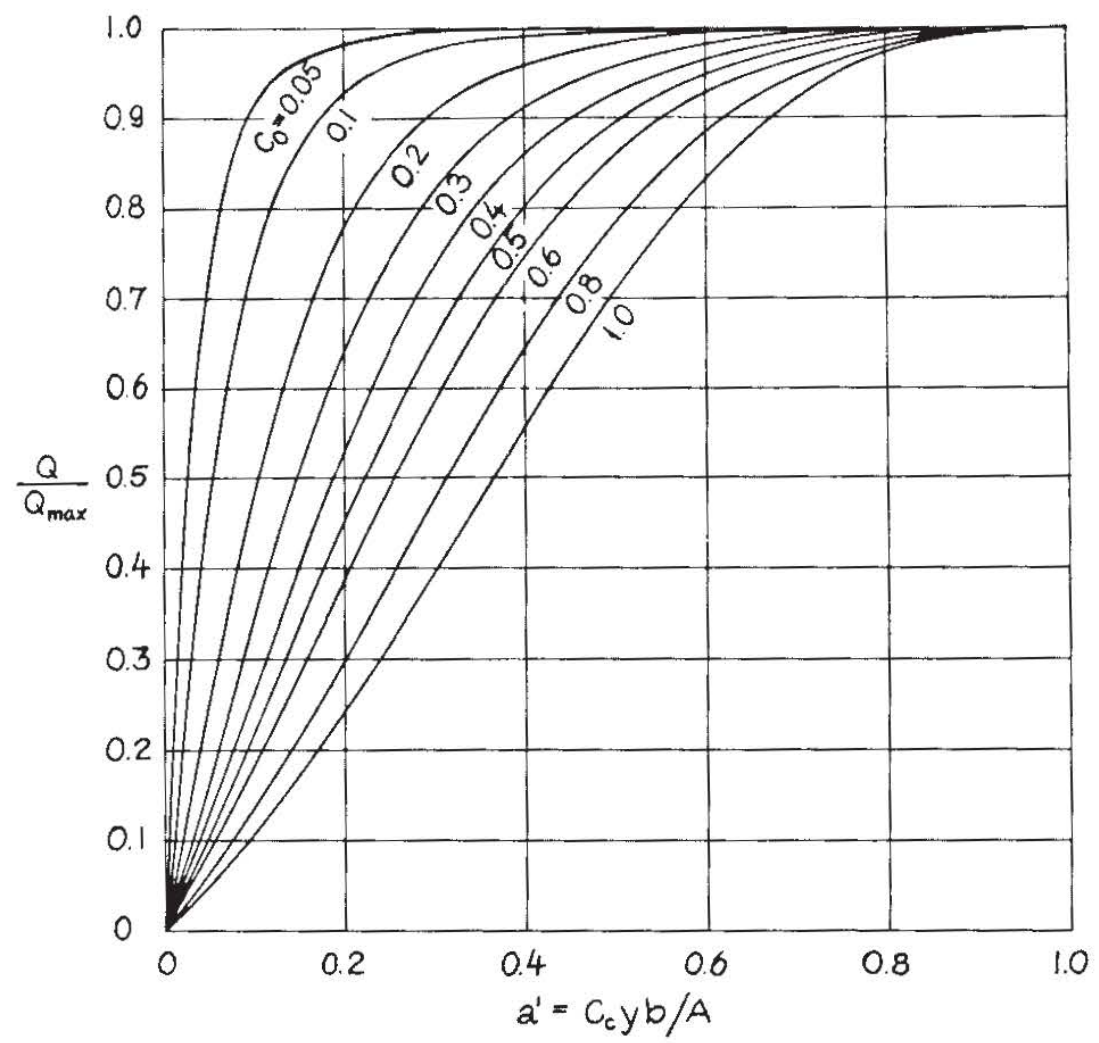

FIG. 4.-VARIATION OF Q/Qmax WITH RELATIVE GATE OPENING a' FOR SUBMERGED FLOW

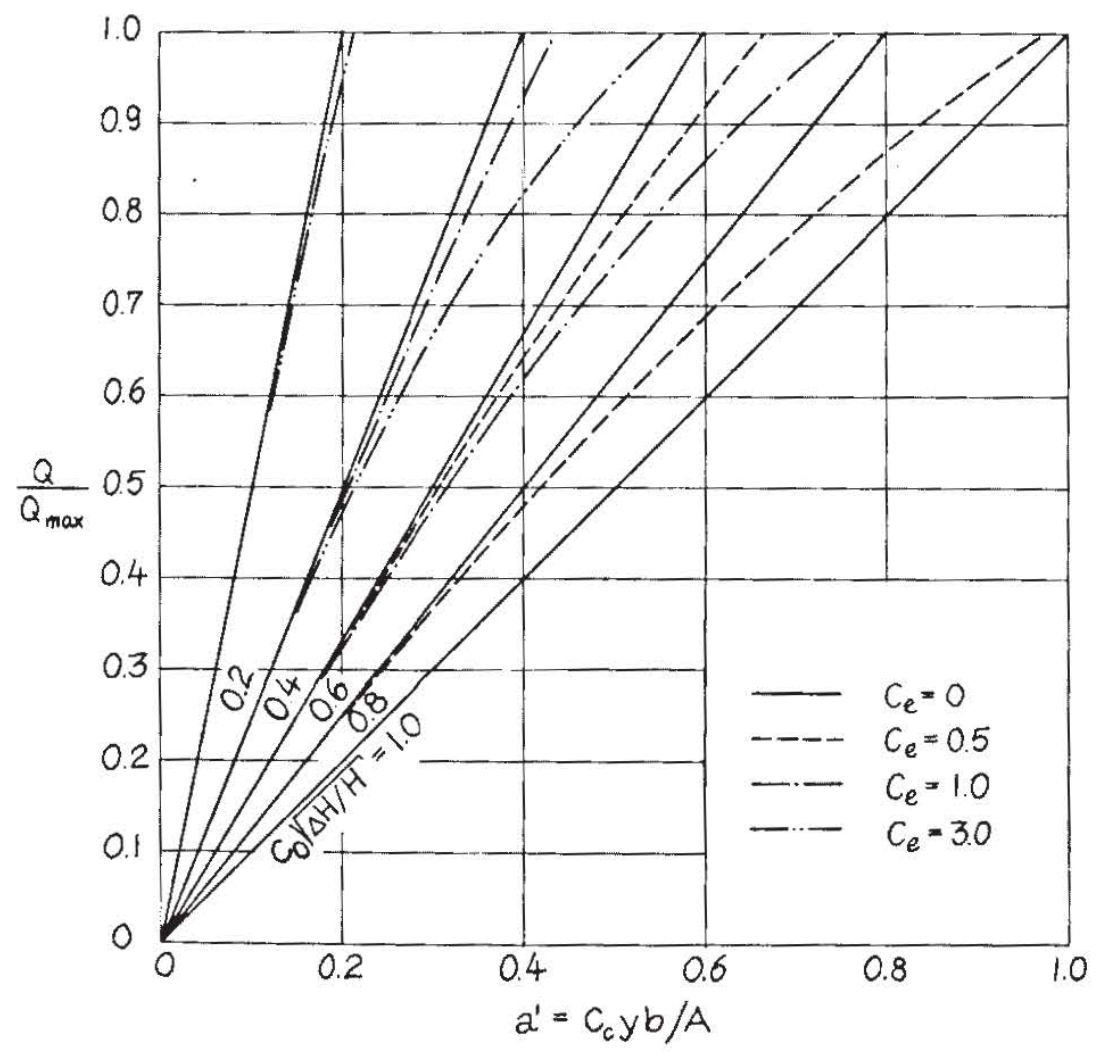

FIG. 5.-VARIATION OF Q/Qmax WITH RELATIVE GATE OPENING a' FOR FREE-SURFACE FLOW 
occur, because $\alpha_{1}$ and $E_{1}$ tend toward moderate values for uniform conduit flow ${ }^{5}$ as $a^{\prime}$ tends toward unity.

The deviation from the mean of the velocities across the contracted jet and the departure from hydrostatic pressure distribution in sections (0) and (1) are ignored in the analysis. They could have been compensated for by introducing $\alpha_{0}$ and $\beta_{0}$ and expanding the expression for $\mathrm{K}$. However, the increased complexity would have resulted in an insignificant gain in accuracy.

Another source of complication in the analysis is the flow above the gate, the rate of which has been expressed with the aid of $\mathrm{A}_{2}$ and $\mathrm{C}$. To facilitate the determination of these quantities it is advisable to create, by appropriate design, conditions for the flow through gate chamber and gate slots that can be better analyzed. It was to this end, for example, that in the Garrison Dam project (A12) water was prevented from passing through the gate slots by means of horizontal steel plates attached to either side of the gate.

Information with respect to the discharge coefficient $\mathrm{C}$ for the face-type gate is obtained from Naudascher's previous work (A16). For the tunnel-type gate $\mathrm{C}$ can be derived as follows. With reference to Fig. 1(a)

$$
\mathrm{Q}^{\prime \prime}=\mathrm{C}_{1} \mathrm{~A}_{1} \sqrt{2 \mathrm{~g}\left(\mathrm{H}-\mathrm{H}_{\mathrm{e}}-\mathrm{h}_{\mathrm{T}}\right)}=\mathrm{C}_{2} \mathrm{~A}_{2} \sqrt{2 \mathrm{~g}\left(\mathrm{~h}_{\mathrm{T}}-\mathrm{h}\right)} \ldots \text { (30) }
$$

in which $\mathrm{A}_{1}$ depicts the minimum cross-sectional area of the upstream passage between gate and gate chamber, $\mathrm{C}_{1}$ and $\mathrm{C}_{2}$ are local discharge coefficients associated with the flow through the upstream and downstream passages, respectively, and $\mathrm{h}_{\mathrm{T}}$ is the piezometric head on the top surface of the gate. By eliminating $\mathrm{h}_{\mathrm{T}}$ from Eq. 30

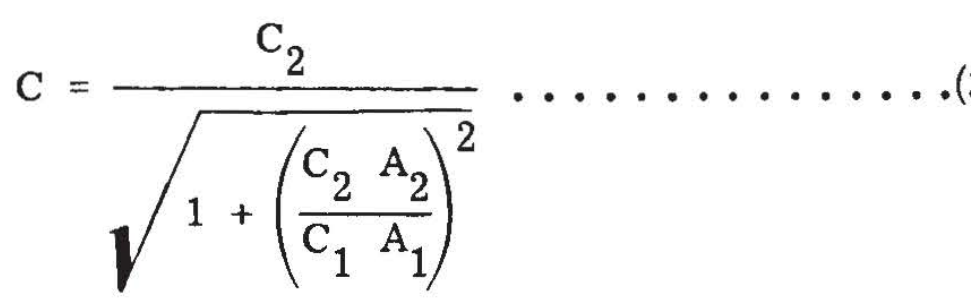

A significant parameter for the flow conditions above the gate is obtained in the combination of terms $\mathrm{CA}_{2} / \mathrm{A}$. Its influence on the total rate of flow is illustrated by Fig. 3(a).

\section{DOWNPULL ANALYSIS}

For steady, irrotational flow the piezometric head along a boundary is completely defined by the distribution of velocity along the boundary relative to a reference velocity $\mathrm{v}_{0}$ and by the magnitude of the latter. 6 The distribution of relative velocity $\mathrm{v} / \mathrm{v}_{0}$ and, hence, the distribution of piezometric head relative to the reference magnitude $v_{0} 2 / 2 \mathrm{~g}$ as well, depend entirely on the flow pattern or the several geometric parameters characterizing it. It follows that the relative distribution of piezometric head is independent of the actual linear scale and the actual magnitude of velocity.

5 Rouse, H. (Editor), "Engineering Hydraulics," John Wiley \& Sons, Inc., New York, N. Y., 1950, p. 401, Fig. 9.

6 Ibid., p. 27. 

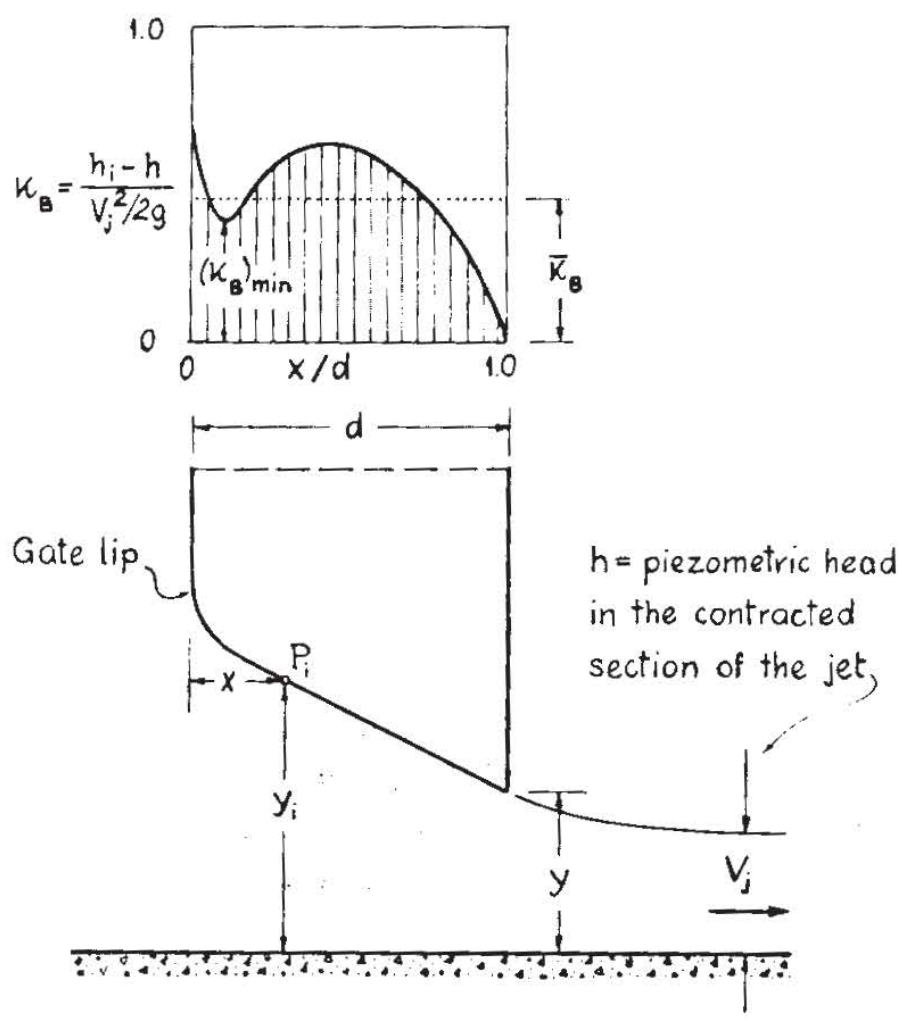

FIG. 6.-DEFINITION SKETCH FOR THE LOCAL AND MEAN VALUES OF ${ }^{\kappa} B$

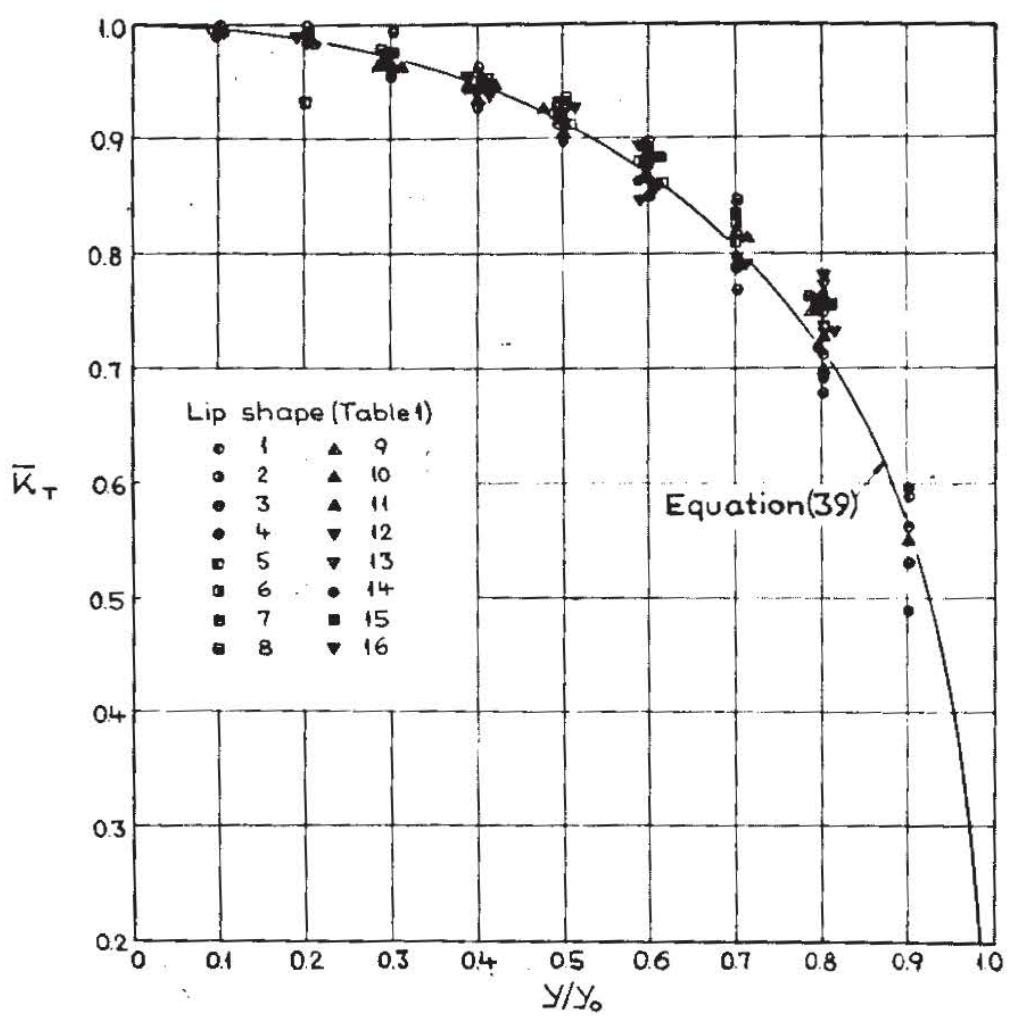

FIG. 7.-VARIATION OF $\kappa_{T}$ WITH RELATIVE GATE OPENING $\mathrm{y} / \mathrm{y}_{0}$ FOR A TUNNEL-TYPE GATE, THE TOP OF WHICH IS SEALED ON THE DOWNSTREAM SIDE 
In general, the flow along the bottom surface of a high-head gate is continuously accelerated, in which case the departure from the conditions of irrotational flow is negligible. Consequently, if $\mathrm{V}_{\mathrm{j}}^{2} / 2 \mathrm{~g}$ is selected as a significant reference,

$$
\kappa_{B}=\frac{\left(\frac{p_{i}}{\gamma}\right)+y_{i}-h}{\frac{v_{j}^{2}}{2 g}}=\frac{h_{i}-h}{\frac{v_{j}^{2}}{2 g}} \ldots \ldots \ldots \ldots
$$

should also be independent of the actual magnitude of velocities, and it should be possible to relate a particular pressure distribution under the gate uniquely to a corresponding gate and conduit geometry (Fig. 6). The difference $\left(h_{i}-h\right)$ of the piezometric heads at a point on the bottom surface of tist oate and at a point of the fully contracted jet, respectively, rather than $h_{i}$ is used in Eq. 32 in order to signify stagnation conditions by the value $\kappa_{\mathrm{B}}=1.0$. Integration of the relative distribution of piezometric head with respect to the gate thickness and the gate width yields

$$
\bar{\kappa}_{B}=\frac{1}{B d} \int_{0}^{d} \int_{0}^{B} \frac{h_{i}-h}{\frac{v_{j}^{2}}{2 g}} d B d x \ldots \ldots . . . . . .
$$

Since the distribution of the piezometric head $\mathrm{h}_{\mathrm{T}}$ on the top surface of the gate is generally constant, it can readily be integrated to yield

$$
\bar{\kappa}_{T}=\frac{1}{B d} \int_{0}^{d} \int_{0}^{B} \frac{h_{T}-h}{\frac{v_{j}^{2}}{2 g}} d B d x \approx \frac{h_{T}-h}{\frac{v_{j}^{2}}{2 g}} \ldots \ldots
$$

Substituting the piezometric heads $\mathrm{h}$ and $\mathrm{h}_{\mathrm{T}}$ from the equations

$$
\frac{\mathrm{h}}{\frac{\mathrm{v}_{\mathrm{j}}^{2}}{2 \mathrm{~g}}}=\frac{\mathrm{H}}{\mathrm{C}_{\mathrm{d}}^{2} \Delta \mathrm{H}}-1-\mathrm{a}^{2} \mathrm{C}_{\mathrm{e}} \ldots \ldots \ldots . . . . .(3
$$

and

$$
\frac{\mathrm{h}_{\mathrm{T}}}{\frac{\mathrm{V}_{\mathrm{j}}^{2}}{2 \mathrm{~g}}}=\frac{\mathrm{H}}{\mathrm{C}_{\mathrm{d}}^{2} \Delta \mathrm{H}}-1-\mathrm{a}^{2} \mathrm{C}_{\mathrm{e}}+\frac{1}{1+\left(\frac{\mathrm{C}_{2} \mathrm{~A}_{2}}{\mathrm{C}_{1} \mathrm{~A}_{1}}\right)^{2}} \ldots \ldots \text { (35) }
$$

which are obtained from the flow analysis, the mean relative piezometric head on the top surface of the gate becomes 


$$
\bar{\kappa}_{\mathrm{T}}=\frac{1}{1+\left(\frac{\mathrm{C}_{2} \mathrm{~A}_{2}}{\mathrm{C}_{1} \mathrm{~A}_{1}}\right)^{2}}
$$

The trend of this relationship is represented in Fig. 8. For the face-type gate, being characterized by $A_{1}=\propto, \bar{\kappa}_{T}$ is equal to unity. For the tunnel-type gate, the validity of Eqs. $35 \mathrm{~b}$ and 36 is restricted to irrotational-flow conditions, as will be examined subsequently.

Knowledge of the pertinent $\bar{\kappa}$-values and the reference velocity $\mathrm{V}_{\mathrm{j}}$ will, finally, permit determination of the corresponding downpull. The primary portion of the downpull, resulting from the difference of the integrated distri-

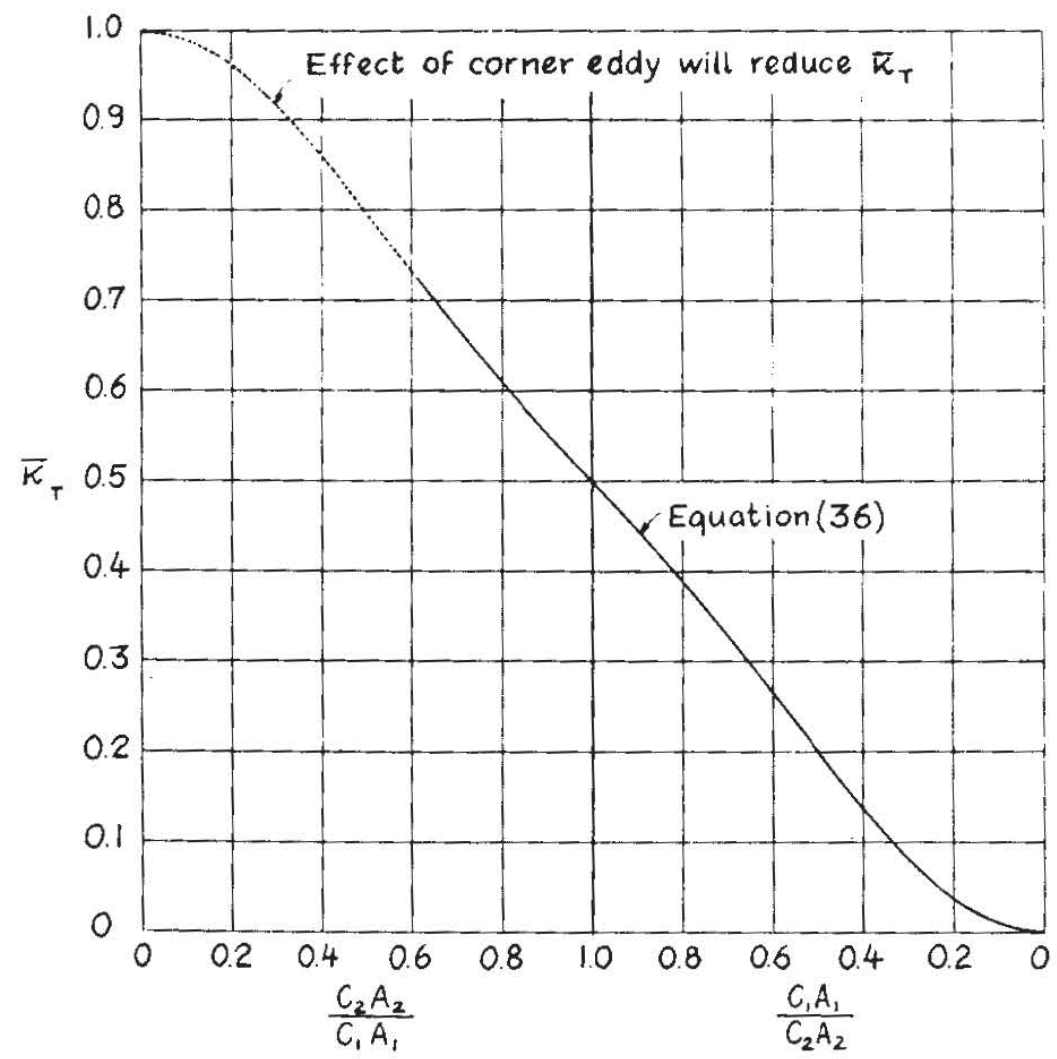

FIG. 8.-EFFECT OF THE FLOW AROUND THE TOP OF A TUNNEL-TYPE GATE ON ${ }^{\kappa} \mathrm{T}$

butions of piezometric head along the top and the bottom surface of the gate, becomes

$$
\mathrm{P}_{1}=\left(\bar{\kappa}_{\mathrm{T}}-\bar{\kappa}_{\mathrm{B}}\right) \mathrm{B} \text { d } \rho \frac{\mathrm{V}_{\mathrm{j}}^{2}}{2} \ldots \ldots \ldots \ldots
$$

The residual portion of the downpull stems from the difference in pressure acting on such horizontal protrusions of the gate as the top seal. If no water 

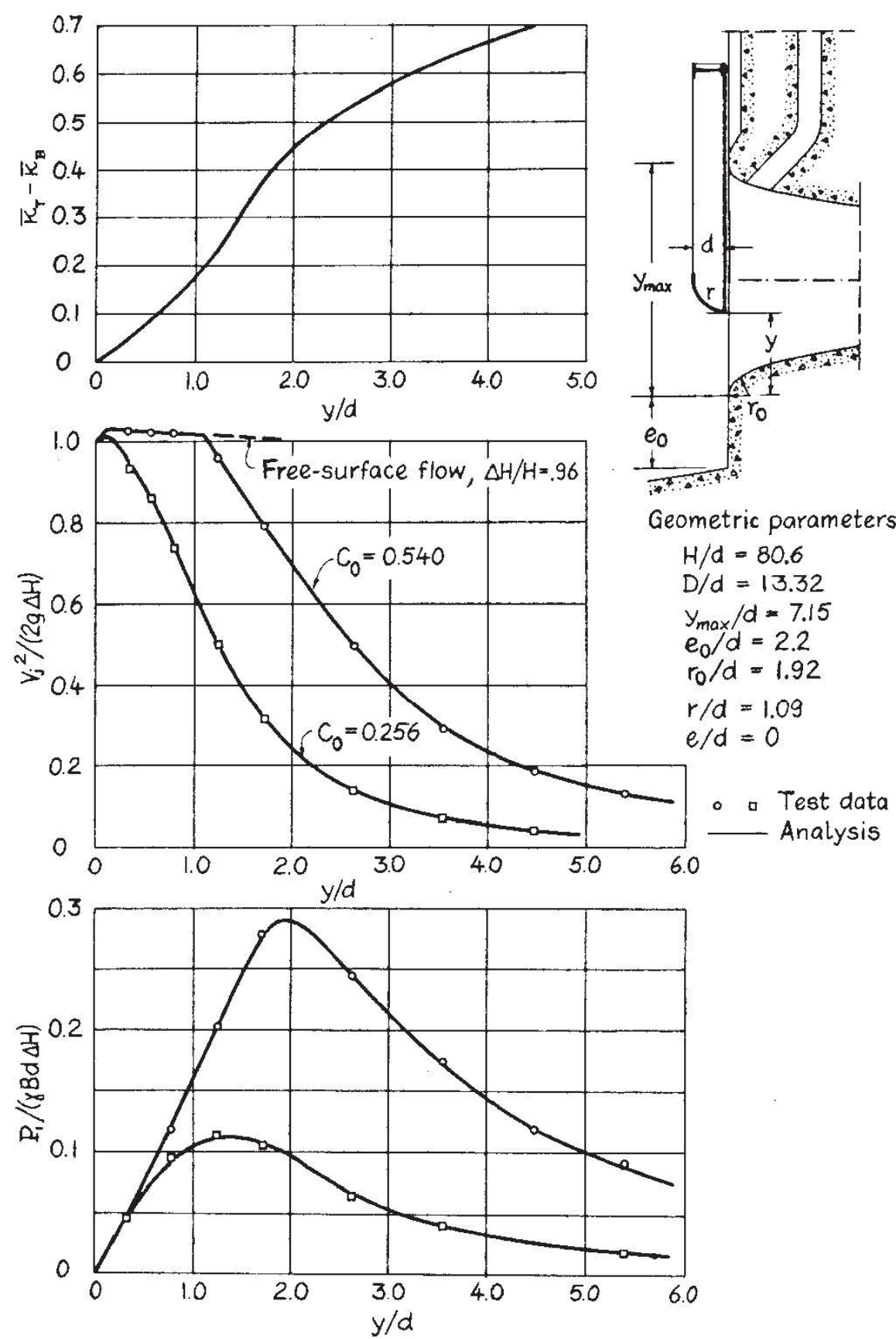

FIG. 9.-EXAMPLE OF DOWNPULL ANALYSIS (A18)

is released above the gate $\left(A_{2}=0\right)$ and the area of the horizontal projection of the top seal is denoted by $A_{S}$, the downpull on the top seal can be written as

$$
\mathrm{P}_{2}=\gamma \mathrm{A}_{\mathrm{S}}\left(\mathrm{h}_{\mathrm{T}}-\mathrm{h}\right)=\bar{\kappa}_{\mathrm{T}} \mathrm{A}_{\mathrm{S}} \rho \frac{\mathrm{V}_{\mathrm{j}}^{2}}{2} \ldots \ldots \ldots
$$

If, on the other hand, a recess is placed in the face opposite to the seal $\left(A_{2} \neq 0\right)$, the water flowing around the top.seal acts to equalize the pressures on the upper and lower sides of the seal and thus to eliminate that part of the downpull. An additional force $\mathrm{P}_{3} \approx \bar{\kappa}_{\mathrm{T}} \mathrm{Bd} \rho \mathrm{V}_{\mathrm{j}}^{2} / 2$ will act in the case of a lip 
shape with an extended skinplate [Fig. 10(a)]. For forces on standard bottom seals see reference A9.

Analysis.-An example is given in Fig. 9 demonstrating how the downpull is determined if the $\bar{\kappa}$-values and the velocity $V_{j}$ are known from experiment and flow analysis, respectively. In the non-dimensional form $P_{1} /(\gamma B d \Delta H)$ the downpull is obtained for a particular gate opening by multiplying the corresponding quantities $\left(\bar{\kappa}_{\mathrm{T}}-\bar{\kappa}_{\mathrm{B}}\right)$ and $\mathrm{V}_{\mathrm{j}}^{2} /(2 \mathrm{~g} \Delta \mathrm{H})$ of the upper two graphs. As seen from the agreement between analysis and test data, the use of one $\left(\bar{\kappa}_{\mathrm{T}}-\bar{\kappa}_{\mathrm{B}}\right)$-curve in combination with two different flow conditions, characterized by $\mathrm{C}_{0}$, leads to the correct value of the downpull, indicating that the $\bar{\kappa}$-values are indeed independent of the absolute flow velocities. The condition of quasi-irrotational flow upstream from and underneath the gate is, of course, satisfied in this case.

As the flow along the upstream boundaries of a gate departs from irrotational conditions due to local deceleration, the flow may separate and thus create new boundary conditions. The mean piezometric head ratios $\bar{\kappa}$ will then no longer depend on the boundary geometry alone, but also on the Reynolds number $\mathbf{R}$ of the flow. Experiments indicate, however, that the relative distribution of piezometric head tends to become independent of the Reynolds number for higher values of $R$ (see Fig. 12 which is for lip shape no. 3, y/yo = 0.4 ). Since $R$ is sufficiently high in practically all high-head installations, the $\bar{k}$-values should be uniquely predictable for a given boundary form even in cases of local flow separation. Fig. 13 shows the flow pattern along the gate bottom, (for lip shape no. $3 \mathrm{y} / \mathrm{y}_{0}=0.4$ and $R=2 \times 10^{5}$ ) viewed from below.

An interesting example of local flow separation is the corner eddy upstream from a tunnel-type gate. According to the concept of irrotational flow, stagnation pressure should be attained in the corner between the conduit roof and the upstream face of the gate. In reality, the pressure is reduced by the action of a quasi-steady eddy. With water flowing around the top of the gate $\left\langle A_{2} \neq 0\right)$ the adverse pressure gradient in the corner, and thus the eddy, may eventually be eliminated in a process analogous to boundary layer suction. It is for this condition that Eqs. 35b and 36 apply correctly (Fig. 8). Usually a combined effect due to flow around the gate top (Fig. 8) and due to the corner eddy (Fig. 7) will prevail in a range of small to moderate ratios of $C_{2} A_{2} / C_{1} A_{1}$. If no water is released above the gate $\left(A_{2}=0\right)$ the corner eddy will reduce the stagnation pressure (represented by $\kappa_{\mathrm{T}}=1.0$ ) as shown in Fig. 7. Interestingly enough, the various experimental results in this figure are closely described by

$$
\bar{\kappa}_{\mathrm{T}}=\frac{1-\mathrm{C}_{\mathrm{c}}}{1-\left(\mathrm{C}_{\mathrm{c}}\right)_{0}} \ldots \ldots \ldots \ldots \ldots
$$

in which $\mathrm{C}_{\mathrm{C}}$ is the coefficient of jet contraction for a slot in a wall perpendicular to the conduit after von Mises ${ }^{7}$ and $\left(C_{c}\right)_{0}$ is the same for a slot-width equal to zero $\left(\mathrm{y} / \mathrm{y}_{0}=0\right)$. The changes in $\kappa_{\mathrm{T}}$ with Reynolds-number in the range $0.7 \times 10^{5}<R<2 \times 10^{5}$ were found to be less than $1 \%$.

The magnitude of the downpull can be controlled in two ways: Through $\bar{\kappa}_{\mathrm{B}}$ by the design of the gate lip, and through $\bar{\kappa}_{\mathrm{T}}$ by the dimensioning of the flow

7 Ibid., p. 34 . 


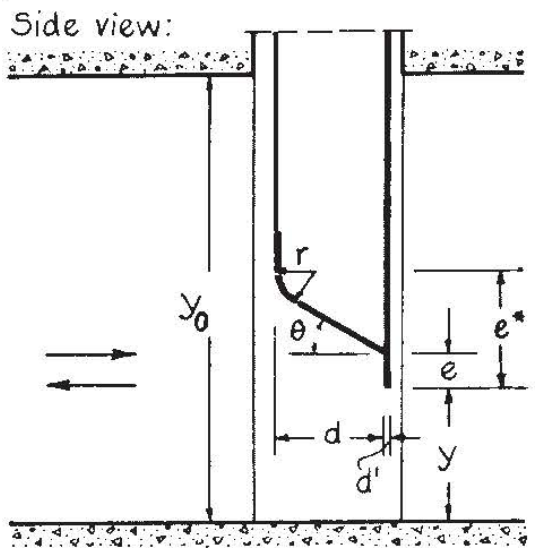

Plan view:

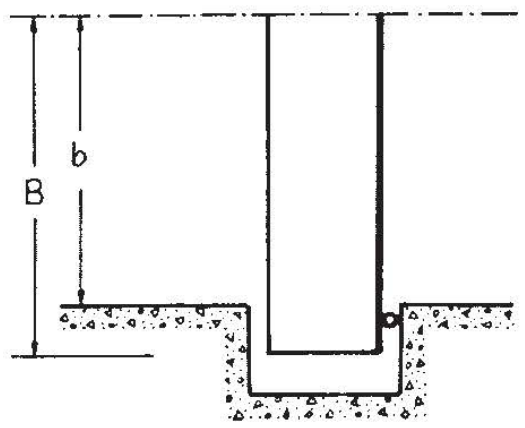

Arrangements of top seal and skin plate
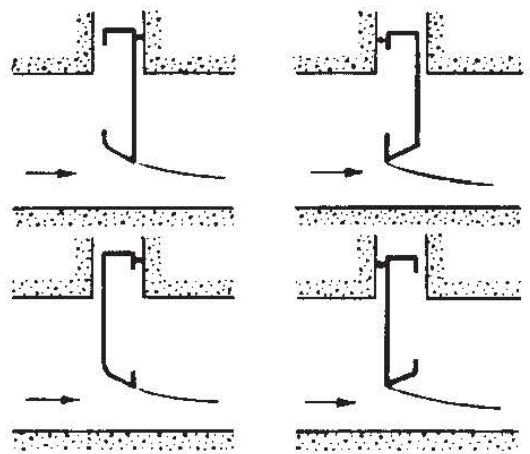

Geometric parameters

$$
\begin{aligned}
& y / d \\
& y_{0} / d \\
& r / d \\
& e / d \\
& \theta \\
& b / d \\
& B / d
\end{aligned}
$$

FIG. 10.-DEFINITION SKETCH OF COMMON GEOMETRY PARAMETERS AND POSSIBLE TOP-SEAL AND SKINPLATE ARRANGEMENTS FOR HIGH-HEAD LEAF GATES
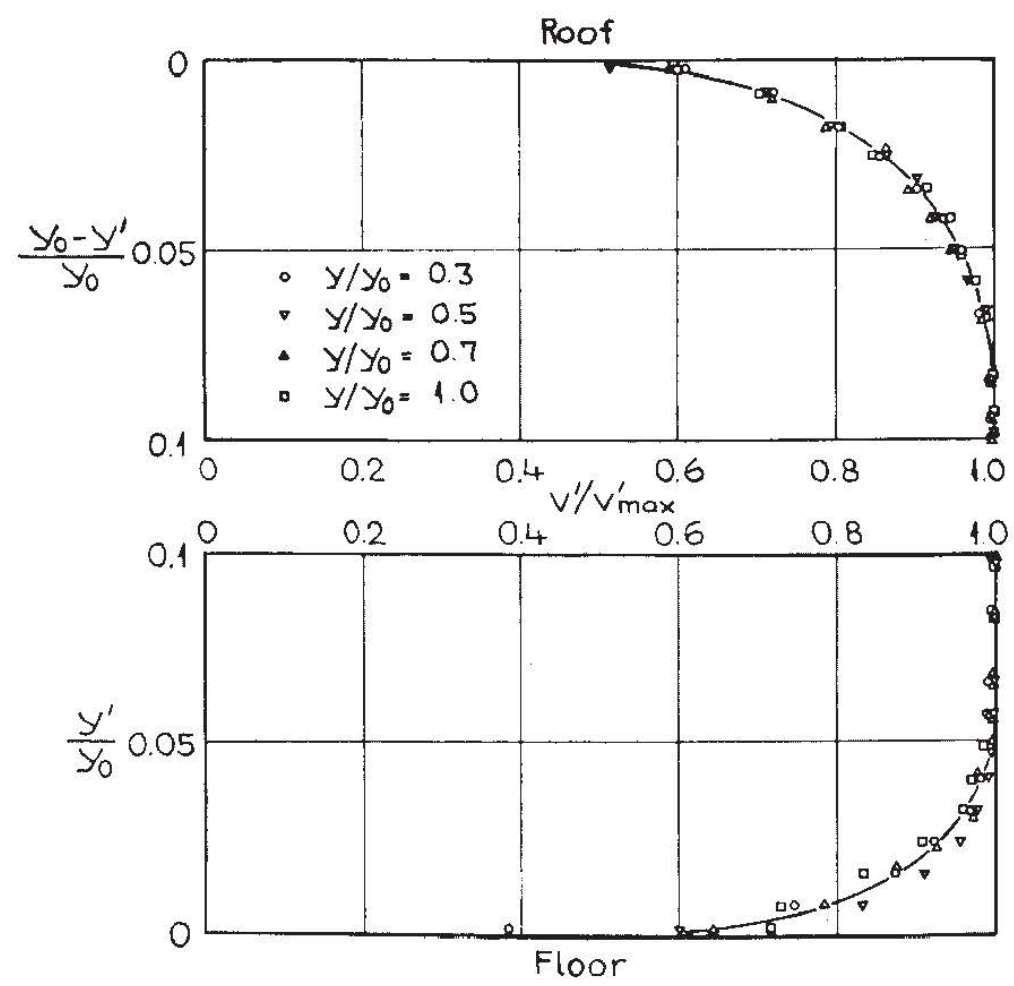

FIG. 11.-DISTRIBUTION OF THE VELOCITY AT A SECTION 16 d UPSTREAM FROM THE GATE FOR $\mathbf{R}=2 \times 105$ AND $y_{0} / d=6$ 
TABLE 1.-INVESTIGATED COMBINATION'S OF GEOMETRY PARAMETERS

\begin{tabular}{r|r|r|r|r|r}
\hline \hline No. & $\theta$, in degrees & $\mathrm{r} / \mathrm{d}$ & $\mathrm{e} / \mathrm{d}$ & $\mathrm{e} / \mathrm{d}$ & $\mathrm{y}_{0} / \mathrm{d}$ \\
\hline 1 & 45 & 0.4 & 0 & 1.17 & 6.0 \\
2 & 30 & 0.4 & 0 & 0.81 & 6.0 \\
3 & 20 & 0.4 & 0 & 0.64 & 6.0 \\
4 & 0 & 0.4 & 0 & 0.40 & 6.0 \\
5 & 0 & 0.4 & 0.15 & 0.55 & 6.0 \\
6 & 0 & 0.4 & 0.30 & 0.70 & 6.0 \\
7 & 0 & 0.4 & 0.85 & 6.0 \\
8 & 0 & 0.4 & 0.60 & 1.0 & 6.0 \\
9 & 0 & 0.2 & 0.15 & 0.35 & 6.0 \\
10 & 0 & 0.2 & 0.30 & 0.50 & 6.0 \\
11 & 0 & 0.2 & 0.45 & 0.65 & 6.0 \\
12 & 0 & 0.6 & 0.30 & 0.90 & 6.0 \\
13 & 0 & 0.6 & 0.45 & 1.05 & 6.0 \\
14 & 30 & 0.4 & 0 & 0.81 & 4.0 \\
15 & 0 & 0.4 & 0.45 & 0.85 & 4.0 \\
16 & 0 & 0.2 & 0.15 & 0.35 & 4.0 \\
17 & 30 & 0.4 & 0 & 0.81 & 8.0 \\
18 & 0 & 0.4 & 0.45 & 0.85 & 8.0 \\
19 & 0 & 0.2 & 0.15 & 0.35 & 8.0 \\
20 & 30 & 0.4 & 0 & 0.81 & 12.0 \\
21 & 30 & 0.4 & 0 & 0.81 & 20.0 \\
\hline
\end{tabular}

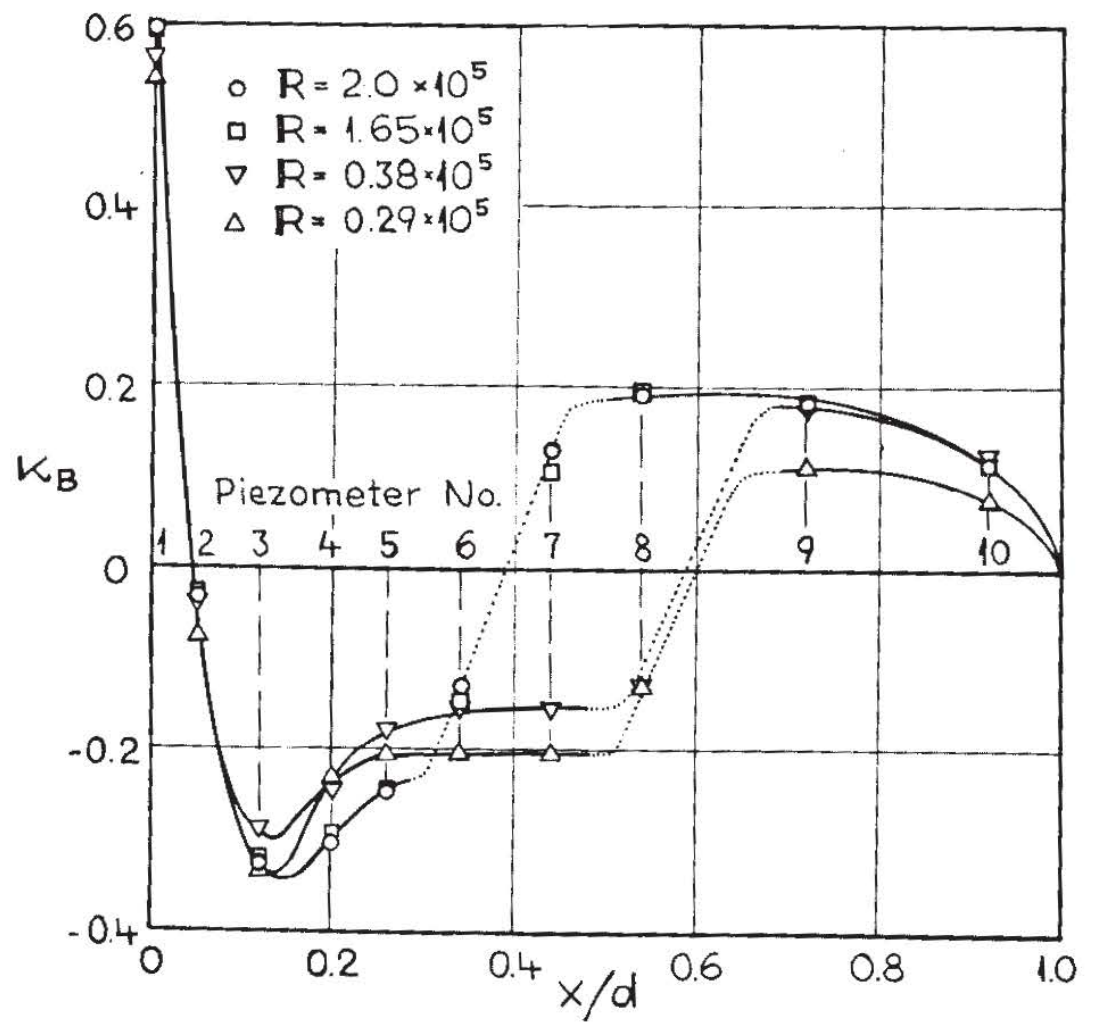

FIG. 12.-VARIATION IN THE DISTRIBUTION OF RELATIVE PIEZOMETRIC HEAD WITH REYNOLDS-NUMBER 


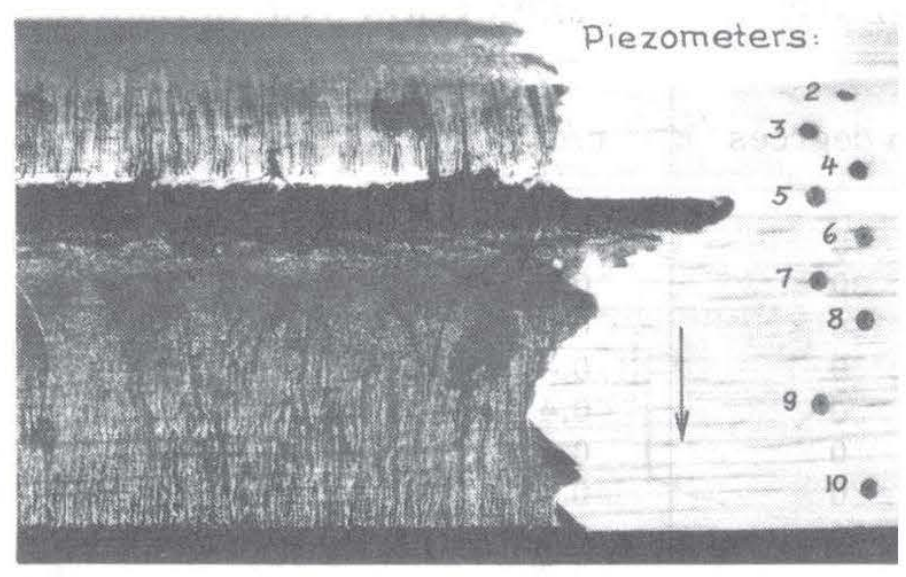

FIG. 13.-FLOW PATTERN ALONG THE GATE BOTTOM AT $\mathbf{R}=2 \times 105$, VIEWED FROM BELOW

passages around the upper portion of the gate. The latter control is of great importance with tunnel-type gates, as seen from Fig. 8. Slight changes in the ratio of the cross-sectional areas $A_{1}$ and $A_{2}$ may change the downpull considerably. Because of the limitation in accuracy with which the design can be reproduced in the field and because of the uncertainties in the determination of the discharge coefficients $\mathrm{C}_{1}$ and $\mathrm{C}_{2}$, it is advisable to provide for an adjustable flow passage-preferably $A_{1}$-in order that predetermined conditions can be realized on the site.

With respect to the four possible combinations of arranging top seal and skinplate [Fig. 10(c)] it is to be noted that the only possible arrangement for face-type gates and the most common for tunnel-type gates is that with seals and skin plate on the downstream side. Eqs. 37 and 38 have therefore been derived for this configuration. With the skinplate on the upstream and the top seal on the downstream side, the equations still apply, except that a buoyancy force must be added in the case of free efflux because the volume of the gate will then in general be free of water. With the top seal on the upstream side as well, only Eq. 38 becomes invalid. Since $\kappa_{\mathrm{T}}=0$ in this case, as follows from Eq. 36, precaution has to be taken that no uplift is induced. Despite the advantage of the reduction in downpull, gates with upstream seals have only been used for relatively low heads because of a number of problems primarily resulting from the extensive vortex action in the gate slots (A27).

\section{EXPERIMENTS}

A two-dimensional tunnel-type gate [Fig. 10(a)] was tested under submerged-flow conditions in an air tunnel of the Iowa Institute of Hydraulic Research with a test section of $10-\mathrm{ft}$ length and $3-\mathrm{ft}$ by $3-\mathrm{ft}$ cross section. The conduit height was varied by a false ceiling. Except for two test series the thickness of the model gate was chosen to be $d=2.5$ in. The distribution of piezometric head along the gate lip was measured at eleven points with piezometric holes of 0.033 -in. diameter, located in the bottom surface of the gate near the center line of the tunnel. The readings were taken by means of mic- 
romanometers with an accuracy of 1/1000 in. of alcohol. The reference piezometric head $h$ was obtained from a piezometer on the downstream side of the gate lip, 0.8d above the lower edge. All measurements were performed with the gate stationary at various partial openings $y$ and at efflux velocities $\mathrm{V}_{\mathrm{j}}$ between $75 \mathrm{fps}$ and $85 \mathrm{fps}$. The velocity head $\mathrm{V}_{\mathrm{j}} 2 / 2 \mathrm{~g}$ was measured as the difference between the reference piezometer and a total-head tube placed in the contracted jet, about 1.25 y downstream from the lower edge of the gate and at an elevation less than $0.5 \mathrm{y}$ above the floor. Traverses with a staticpressure tube verified the assumption that the piezometric heads on the downstream side of the gate and in the fully contracted section of the jet were essentially equal.

From a dimensional analysis, the distributions of piezometric head on the top and the bottom surface of the gate can both be expressed in the nondimensional functional form

$\frac{h_{T}-h}{v_{j}^{2} / 2 g}, \frac{h_{i}-h}{v_{j}^{2} / 2 g}=\Phi^{\prime}\left\{R, F, K, \frac{x}{d}, \frac{[y(t)]}{d}, \frac{y_{0}}{d}, \theta, \frac{e}{d}, \frac{r}{d}, \frac{b}{d}, \frac{B}{d}, \frac{\left[v^{\prime}\left(y^{\prime}\right)\right]}{v_{j}}\right\} \ldots$

In the experiments under consideration, which were restricted to submerged flow without cavitation, the Froude number $F$ and the cavitation $\boldsymbol{K}$ had no ef fect. For the condition of stationary gate positions $y(t)=y=$ const. With the additional restriction to two-dimensional flow $(b / d \rightarrow B / d \rightarrow \infty)$ the above relationship reduces to

$$
\bar{\kappa}_{\mathrm{T}}, \bar{\kappa}_{\mathrm{B}}=\Phi\left\{\mathrm{R}, \frac{\mathrm{y}}{\mathrm{d}}, \frac{\mathrm{y}_{0}}{\mathrm{~d}}, \theta, \frac{\mathrm{e}}{\mathrm{d}}, \frac{\mathrm{r}}{\mathrm{d}}\right\} \ldots \ldots
$$

if the terms to the left of the equation are combined with $\mathrm{x} / \mathrm{d}$ to yield the mean values $\bar{\kappa}$ according to Eqs. 33 and 34 . The last parameter in Eq. 40 , which describes the velocity profile at a distance $x^{\prime}$ upstream from the gate, is omitted in Eq. 41, because its effect has not been investigated. The specific velocity profile for which the experiments with $y_{0} / d=6$ were conducted is shown in Fig. 11. It was found to be almost independent of the gate opening, the gate geometry and the Reynolds number within the range of investigation. Similar conditions prevailed for the other relative tunnel heights $y_{0} / d$.

As is apparent from Eq. 41, the experiments were confined to the investigation of $\bar{\kappa}$ as a function of the Reynolds number and five of the most influential boundary parameters interpreted in Fig. 10. Note that the face-type gate is represented in this study by large $\mathrm{y}_{0} / \mathrm{d}$ and $\mathrm{y}_{\max }<\mathrm{y}_{0}$. (Under these conditions, the effect of the corner eddy diminishes and $y_{0}$ becomes equivalent to H, see Fig. 1.)

Results. - The effect of the Reynolds number on the distribution of piezometric head along an inclined gate bottom is shown in Fig. 12 for the representative inclination $\theta=20^{\circ}$. Both Figs. 12 and 13 give evidence of local flow separation with subsequent reattachment. The flow pattern of Fig. 13 was obtained by means of a compound of oil and pigment particles which was applied to the gate surface and then subjected to the flow (A29). The zone of separation is marked by an accumulation of pigment particles, and by a region of nearly constant piezometric head followed by a sudden pressure rise, respectively. 
As the Reynolds number increases, the separation zone is reduced until a critical value is reached beyond which the flow pattern and hence the distribution of piezometric head remain practically invariant. The critical Reynolds number for the conditions of Fig. 12 was found to be about $1.3 \times 10^{5}$. Qualitative measurements with a hot-wire anemometer indicated that this critical value marked the end of the transition to turbulence in the boundary layer immediately upstream from the onset of separation.

The effect of the Reynolds number on the downpull parameter $\bar{\kappa}_{\mathrm{B}}$ is demonstrated in Fig. 14. From this diagram it becomes evident whether or not the critical Reynolds number has been reached for a particular lip shape. All subsequent experiments were conducted at Reynolds numbers around $2 \times 10^{5}$.

The influence of the various geometric parameters upon $\bar{\kappa}_{\mathrm{B}}$ is illustrated by Figs. 15 to 18 . The data for $\kappa_{\mathrm{B}}$ were obtained by graphical integration of the measured distribution of piezometric head along the bottom surface of the gate according to Eq. 33. The corresponding data for $\bar{\kappa}_{\mathrm{T}}$ pertaining to the top surface of the gate follow immediately from Eq. 34. For a downstream top seal that remains in contact with the wall of the gate chamber during operation, $\bar{\kappa}_{\mathrm{T}}$ was found to be almost independent of the gate geometry, as shown in Fig. 7. The evaluation of $\bar{\kappa}_{\mathrm{T}}$ for other top seal arrangements has been considered in the analytical part of this paper.

The coefficient of contraction was determined by using its definition

$$
\mathrm{C}_{\mathrm{c}}=\frac{\mathrm{Q}^{\prime}}{\left(\mathrm{b} \mathrm{y} \mathrm{V}_{\mathrm{j}}\right)} \ldots \ldots \ldots \ldots \ldots \ldots
$$

in which $Q^{\prime} / b$ is the rate of flow per unit width, obtained by integrating the upstream velocity profile (Fig. 11). The accuracy of this procedure diminished substantially with decreasing gate opening $y$. The variation of $\mathrm{C}_{\mathrm{c}}$ with $\mathrm{y} / \mathrm{y}_{0}$ for some combinations of the investigated geometric parameters is represented in Fig. 22.

Analysis.-All experimental data represented in this paper are strictly valid only for submerged-flow conditions. The deviations in the $\bar{\kappa}$-terms for free efflux will presumably be small, however, unless the lip shape causes complete separation. The influence of the velocity profile upstream from the gate is conceivably of even smaller order. With regard to the Reynoldsnumber effect, the critical value of $R$ was exceeded only in the investigation of the lip shapes with inclined gate bottom. For lip shapes with a projected skin plate, the Reynolds number still affected $\bar{\kappa}_{B}$ at the value $R=2 \times 10^{5}$ at which the experiments were conducted. As evident from Fig. 14, this effect reduced to a negligible amount with increasing $\mathrm{e}^{*} / \mathrm{d}$ and, remarkably, also for the condition of complete separation from the gate lip (lip shape No. 9).

For a given relative gate opening $\mathrm{y} / \mathrm{d}$, the ratio of the piezometric head at any point of the gate lip to the velocity head $V_{j}^{2} / 2 \mathrm{~g}$ decreases with decreasing angle of inclination $\theta$ of the bottom surface, with decreasing relative length of the projection of the downstream skinplate $\mathrm{e} / \mathrm{d}$, and with increasing relative conduit height $y_{0} / d$. The piezometric heads are generally larger than the reference head $\mathrm{h}$ downstream from the gate. The occurrence of minimum piezometric heads smaller than $\mathrm{h}$, marked by $\left(\bar{\kappa}_{\mathrm{B}}\right)_{\text {min }}<0$ ( see Fig. 6 ), is of interest with respect to the susceptibility of a lip shape to cavitation. As shown in Fig. 20, $\left(\kappa_{\mathrm{B}}\right)_{\mathrm{min}}$ is a function of the relative gate opening $\mathrm{y} / \mathrm{d}$ and 

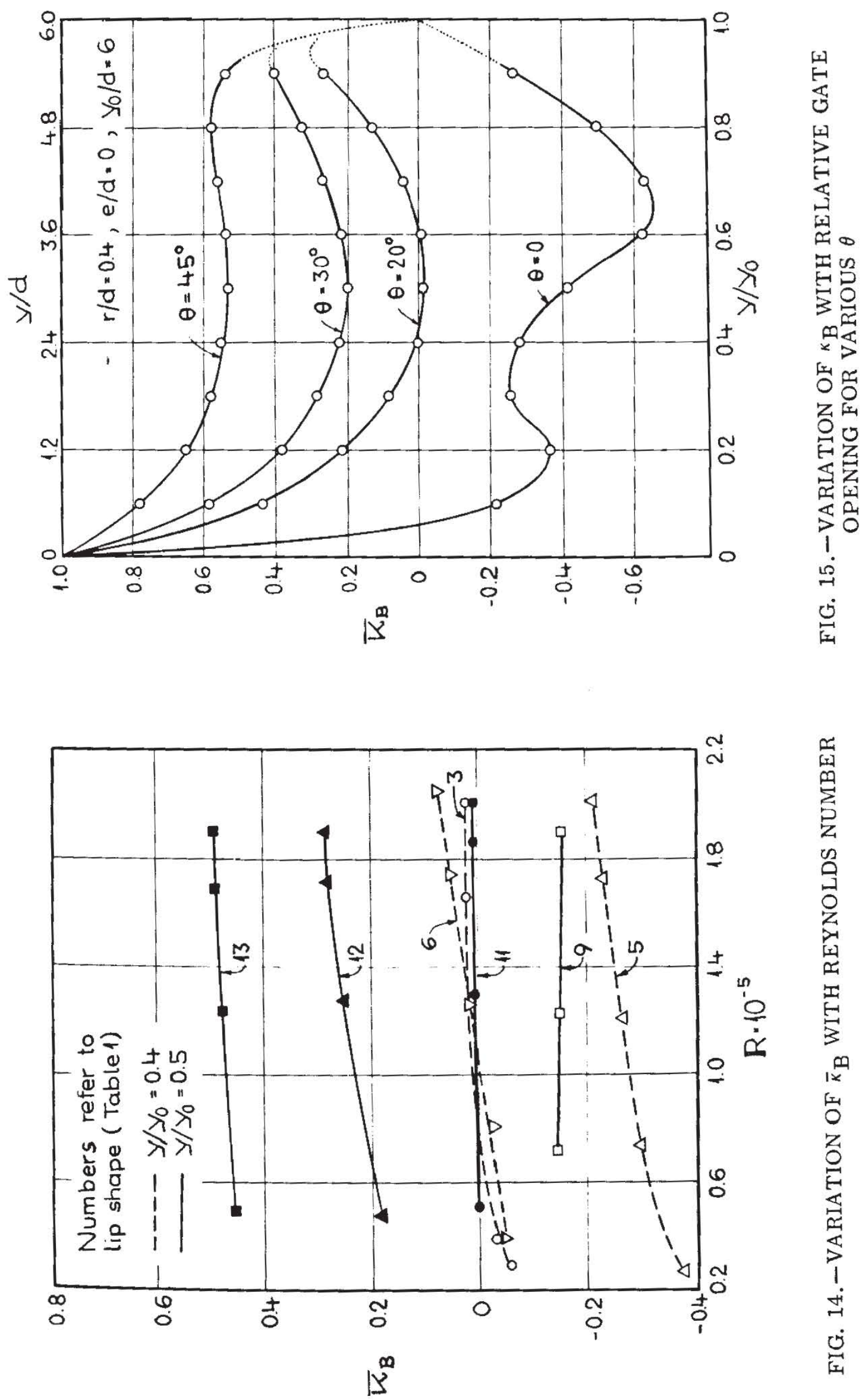

焉是 


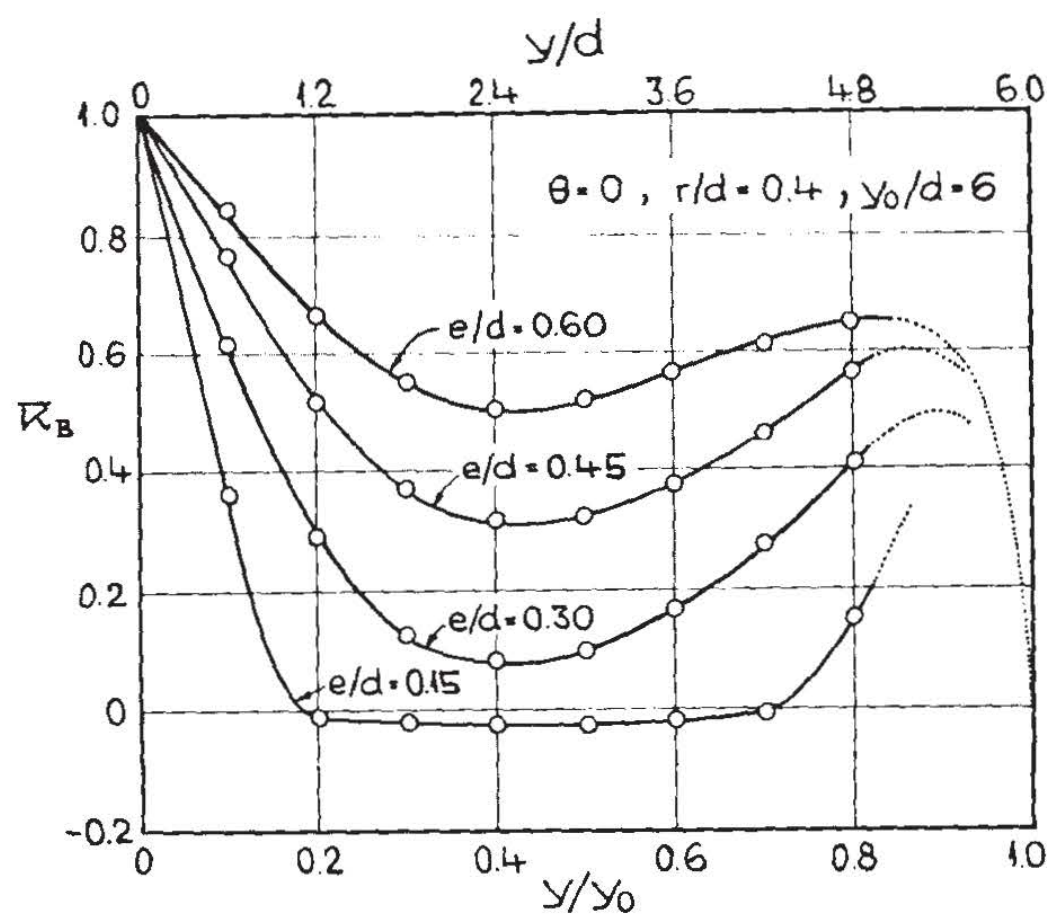

FIG. 16.-VARIATION OF ${ }^{K}$ WITH RELATIVE GATE OPENING FOR VARIOUS e/d

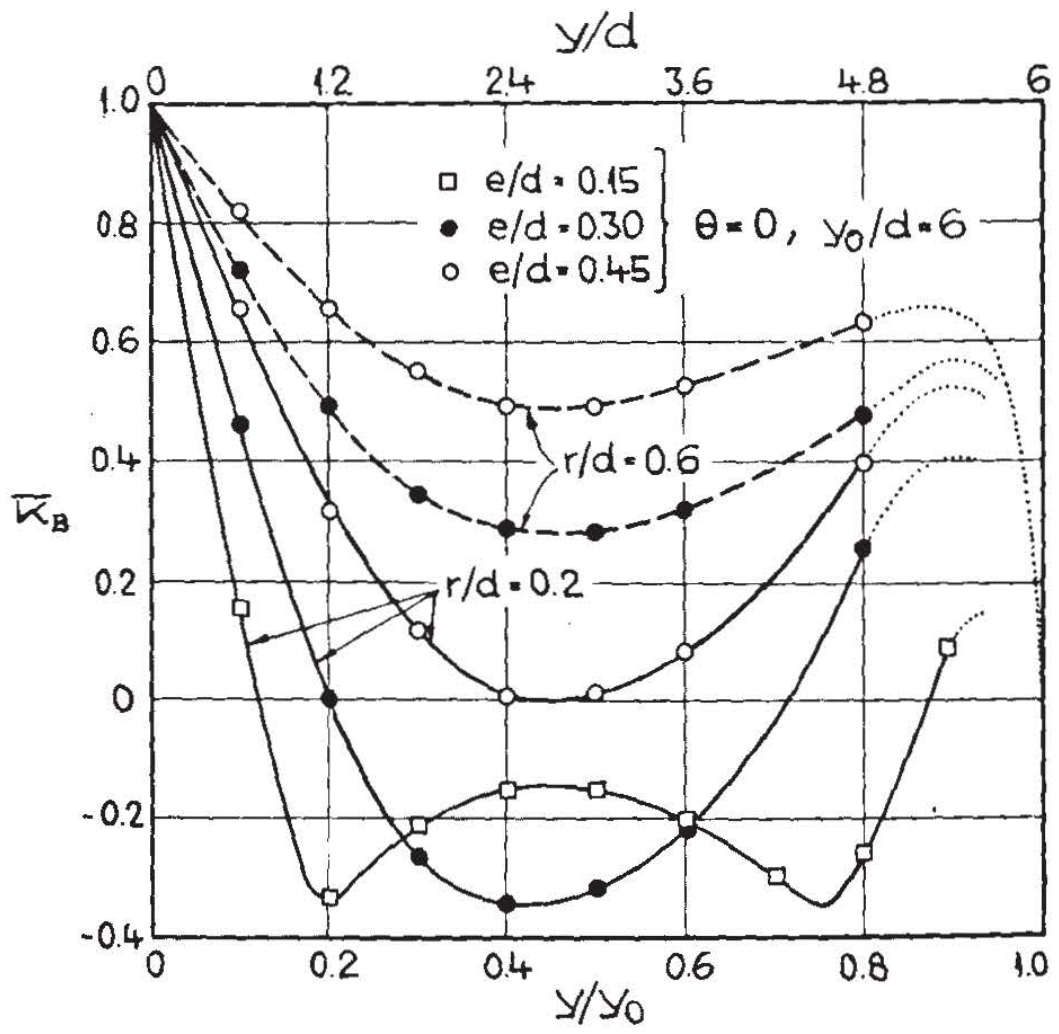

FIG. 17.-VARIATION OF ${ }^{\kappa}$ B WITH RELATIVE GATE OPENING FOR VARIOUS $\mathrm{r} / \mathrm{d}$ 


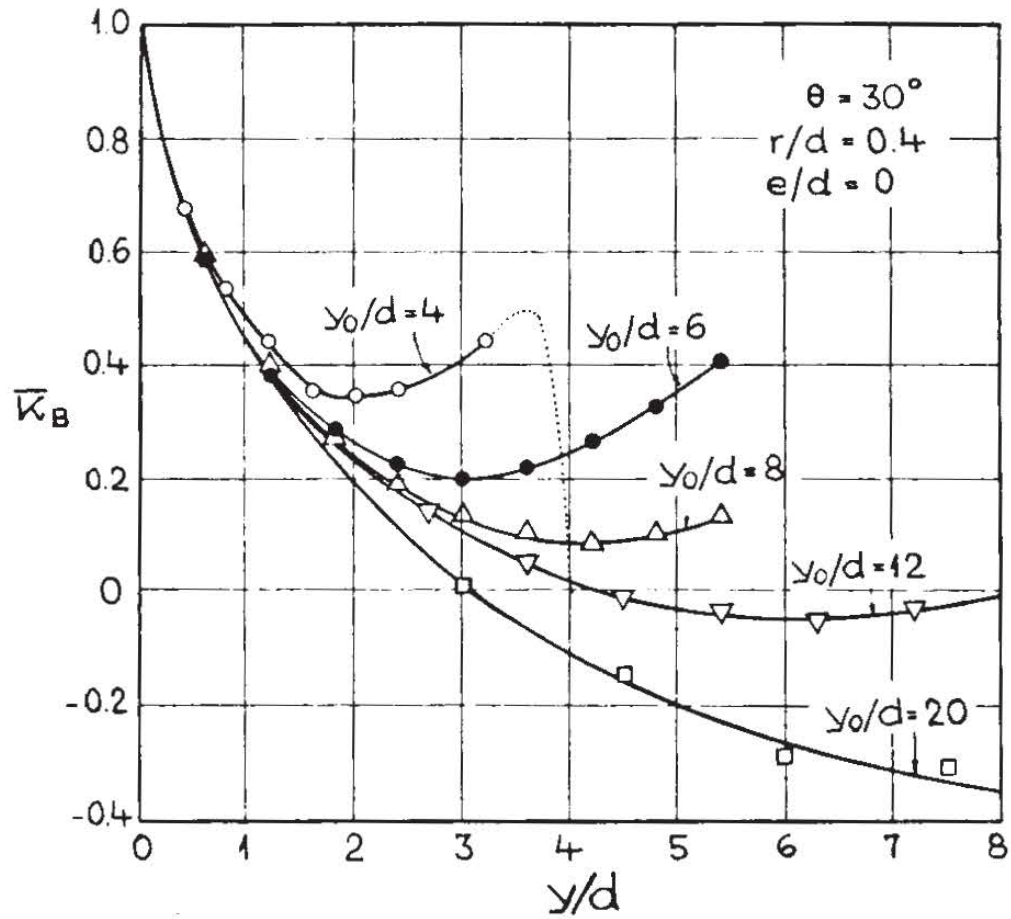

FIG. 18. - VARIATION OF ${ }^{\kappa} \mathrm{B}$ WITH RELATIVE GATE OPENING FOR VARIOUS $\mathrm{y}_{0} / \mathrm{d}$
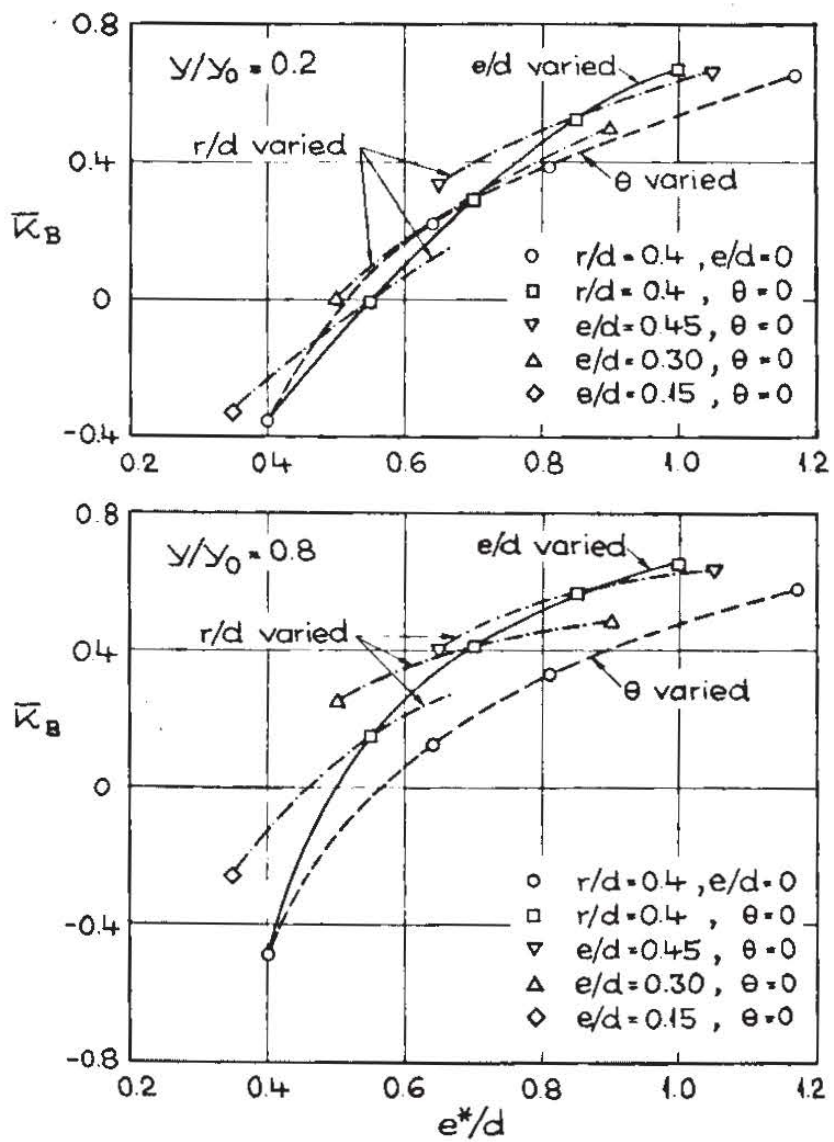

FIG. 19.-VARIATION OF ${ }^{\kappa} \mathrm{B}$ WITH $e^{*} / \mathrm{d}$ FOR $\mathrm{y}_{0} / \mathrm{d}=6$ 

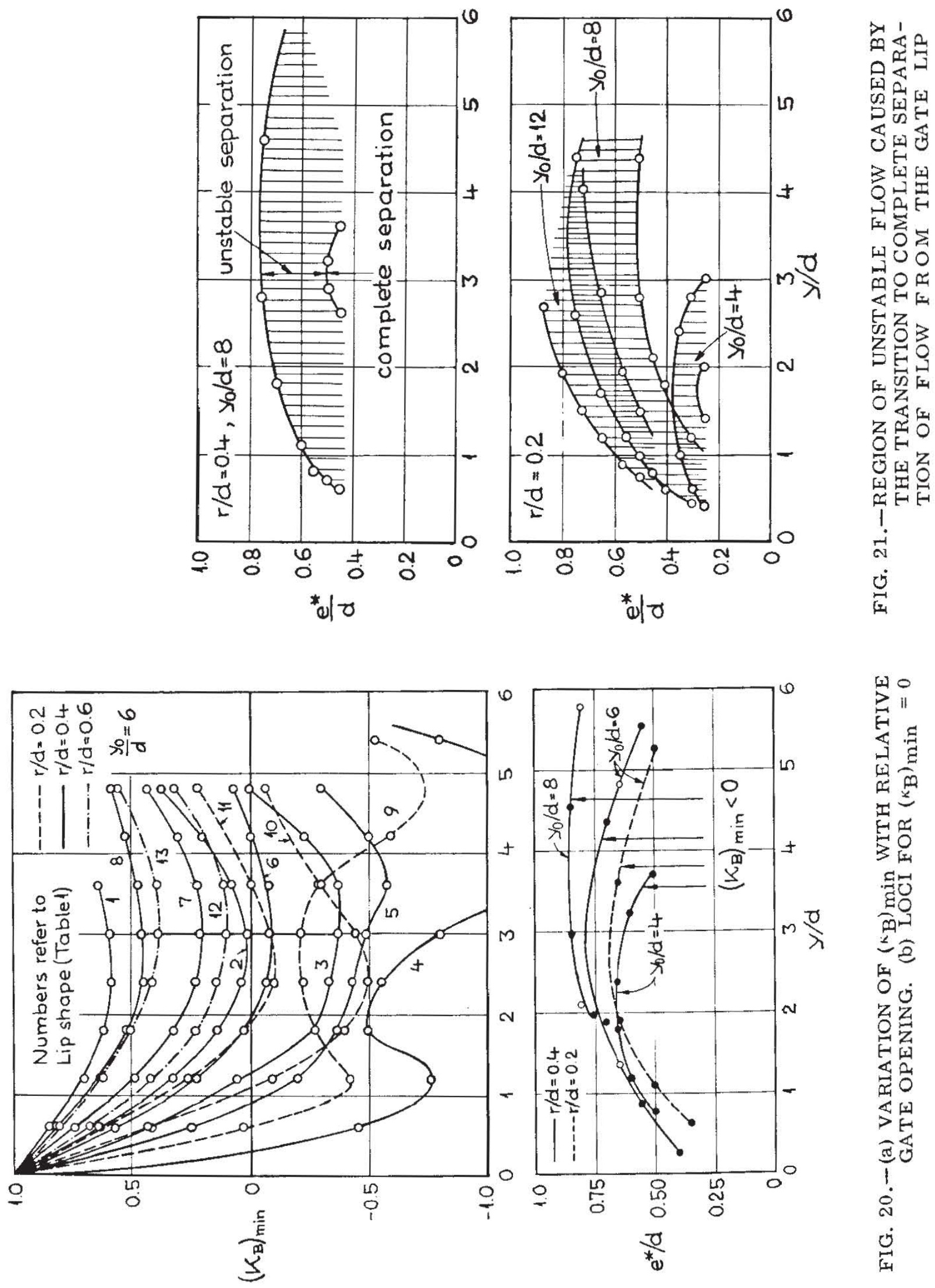

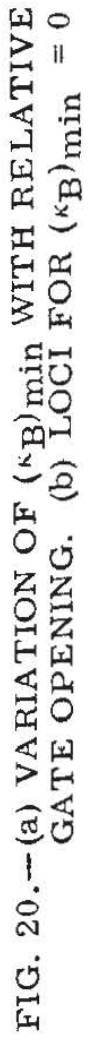



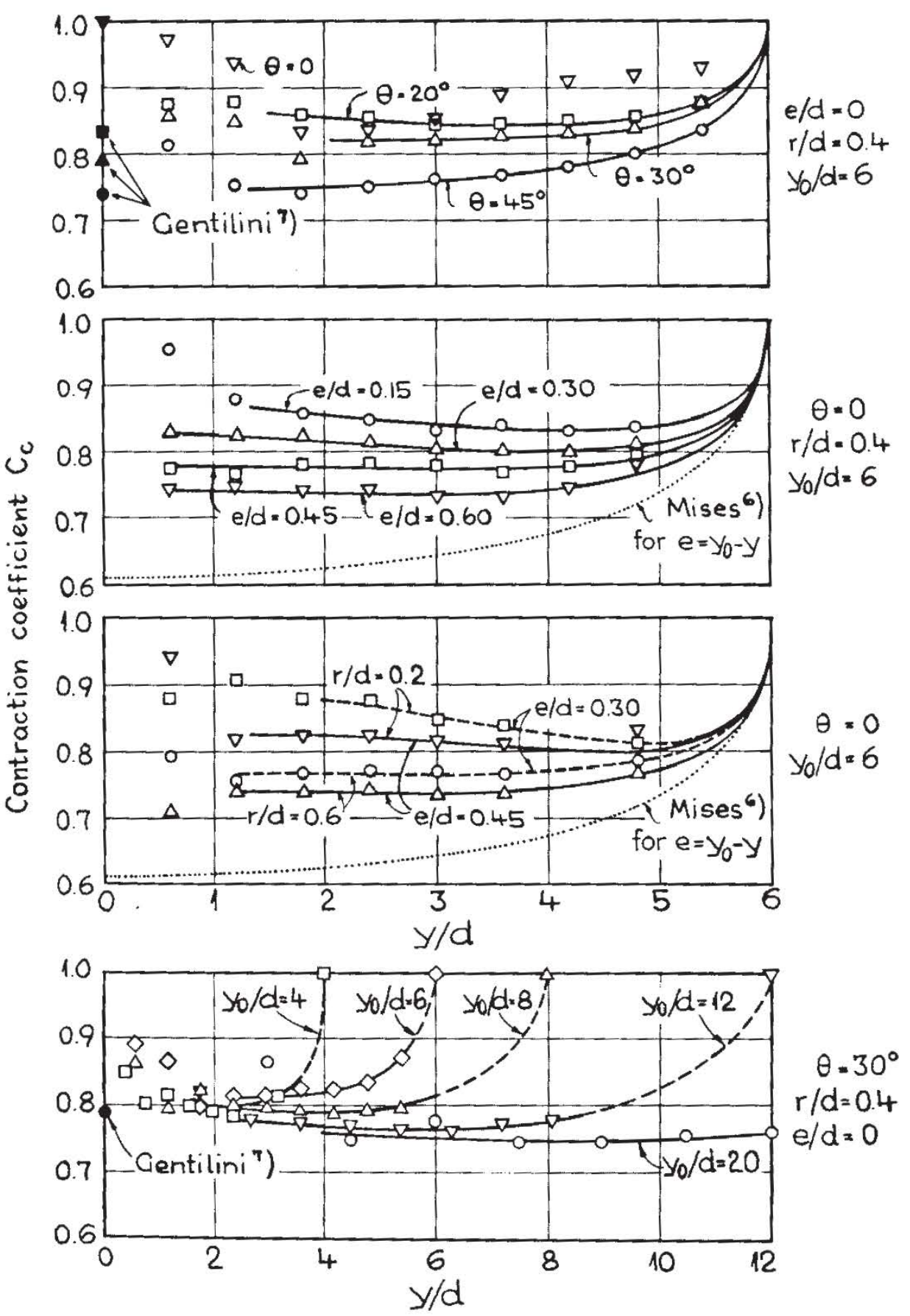

FIG. 22.-VARIATION OF $\mathrm{C}_{\mathrm{c}}$ WITH RELATIVE GATE OPENING FOR VARIOUS $\theta, e / d, r / d, A N D y_{0} / d$. (SUBMERGED FLOW. $)^{8}$

may become negative for small values of $\theta$ or $\mathrm{e} / \mathrm{d}$. The loci for the limiting condition $\left(\kappa_{\mathrm{B}}\right)_{\min }=0$, when plotted with respect to $\mathrm{e}^{*} / \mathrm{d}$ and $\mathrm{y} / \mathrm{d}$, follow a continuous curve for each relative radius $\mathrm{r} / \mathrm{d}$ and relative conduit height $\mathrm{y}_{0} / \mathrm{d}$, regardless of whether the bottom surface is inclined or followed by a projection of the skinplate. Fig. 20 can be used to determine whether subatmospheric pressures along the gate lip may developduring the gate operation for a given design parameter $\mathrm{e}^{*} / \mathrm{d}$ and a given reference head $\mathrm{h}$. Piezometric heads $\mathrm{h}<0$,

\footnotetext{
${ }^{8}$ Gentilini, B., “Encoulement sous les vannes de fond inclinée ou à secteur," La Houille Blanche, Grenoble, France, Vol. 2, 1947, p. 145.
} 
of interest in this respect, are generally confined to free or partially submerged efflux at small gate openings and depend in magnitude on the dimensioning of the aeration facilities. It is important to note that the diagrams of Fig. 20 refer to mean values of the actually fluctuating piezometric heads and that lower values may hence be reached instantaneously. In the case of boundary forms causing separation, moreover, cavitation is known to begin within the fine-scale eddies formed at the separation surface long before the boundary pressure attains its vapor limit.

Local separation of flow with reattachment to either the inclined bottom or to the projection of the downstream skinplate occurs for the majority of the investigated lip shapes. Separation is reduced and ultimately eliminated as the gate lip approaches either the floor or the roof of the conduit. The smaller the relative conduit height $y_{0} / d$, the less the tendency toward separation. An increase in $\mathrm{r} / \mathrm{d}$ or $\theta$ also reduces separation. For $\mathrm{y}_{0} / \mathrm{d}=4$ and $\mathrm{r} / \mathrm{d}=0.4$ the flow remains completely attached to the bottom surface provided the latter is inclined at $30^{\circ}$ or more. Extremely flat lip shapes cause the flow to separate completely from the gate lip. The regions of transition from flow that is always attached to the trailing edge of the gate lip to completely separated flow are represented in Fig. 21 in terms of $e^{*} / d$ and y/d. Exceptionally high pressure fluctuations, observed at gate openings within the transition regions of this figure, suggest that completely separated and reattached flows can alternate rapidly in this range. Since it is conceivable that such pressure fluctuations might excite gate vibration, it is advisable to choose $\mathrm{e}^{*} / \mathrm{d}$ well above the upper critical values given by Fig. 21 .

From a constructional viewpoint, $\mathrm{e}^{*} / \mathrm{d}$ should be as small as possible. To facilitate, for a predetermined $e^{*} / d$, the selection of a lip shape of minimum downpull (equivalent to maximum $\kappa_{\mathrm{B}}$ ), some of the data of Figs. 15 to 18 were replotted in Fig. 19 to yield $\bar{\kappa}_{\mathrm{B}}$ as a function of $\mathrm{e}^{*} / \mathrm{d}$. Similar diagrams can be derived for other values of $y / y_{0}$. According to such diagrams, the downpull is essentially a function of the overall parameter $e^{*} / d$, regardless of the combination of the particular parameters $\mathrm{r} / \mathrm{d}, \theta$, and $\mathrm{e} / \mathrm{d}$, at least within the range of investigation. For equal $e^{*} / d$, the projected skinplate is seen to be only slightly more favorable than the inclined gate bottom, and an increase in curvature $\mathrm{r} / \mathrm{d}$ is slightly less effective than an increase in $\theta$ or $\mathrm{e} / \mathrm{d}$. Of course, the minimum downpull should not be the only criterion in the selection of a lip shape. The possibility of cavitation and of unstable flow conditions should be given primary consideration. If cavitation plays a role, for example, then any inclined gate bottom with a sufficient rounding, which does not cause flow separation, will be superior to a gate with skinplate projection of corresponding downpull characteristics, for reasons discussed above.

\section{CONCLUSIONS}

The analysis of the rate of flow past a high-head leaf gate involved empirical coefficients, the influence of which was proved to be small except for the contraction coefficient. The analysis of the hydraulic downpull acting on a high-head leaf gate was accomplished by treating separately the effects of flow and geometry. It was shown that the downpull for any flow condition and any boundary geometry can be determined in terms of the reference velocity 
head $v_{j} 2 / 2 g$, which follows from the flow analysis, and in terms of nondimensional $\bar{K}$-values, which were evaluated for some of the most significant boundary parameters experimentally. The details of the gate-lip geometry were found to be of minor influence as far as the mean downpull is concerned; with respect to the fluctuating downpull, however, they proved to be important. While the mean downpull depends essentially on the overall parameter $e^{*} / d$, the fluctuation about the mean is a function of each one of the specific parameters $\mathrm{r} / \mathrm{d}, \mathrm{e} / \mathrm{d}$, and $\theta$. The most violent pressure fluctuations were observed near the transition to complete separation of flow from the gate lip. The conditions for this unstable flow separation as well as the conditions for the development of subatmospheric pressure along the gate lip were examined and analyzed.

It is hoped that the method of analyzing and presenting downpull data, as described in this paper, will prove useful in generalizing other experimental work as well, and that, ultimately, sufficient design information will become available to permit not only the prediction of the downpull for a given boundary geometry but also the synthesis of the composite form which would most favorably fit the requirements of a specific project.

The analysis reported herein is based on earlier investigations of the senior writer and was presented by him at the ASCE Conference at Omaha in May 1962. The experimental part of the paper represents an excerpt from two thesis projects (A29 and A30) conducted by the junior writers in partial fulfillment of the requirements for the degree of Master of Science in the Department of Mechanics and Hydraulics of the University of Iowa, Iowa City, Iowa, under the supervision of the senior writer, and was presented at the ASCE Conference at Milwaukee in May 1963. The paper was critically reviewed by Hunter Rouse, F. ASCE Director of the Iowa Institute of Hydraulic Research.

\section{APPENDIX I.-NOTATION}

The following letter symbols have been adopted for use in this paper:

A

$\mathrm{A}_{1}$

$\mathrm{A}_{2}$

$A_{C}$

$A_{S}$

a

$a^{\prime}$

$=$ Cross-sectional area of the conduit;

= minimum cross-sectional area between upstream face of the gate and upstream wall of the gate chamber;

= cross-sectional area of the contracted jet issuing from the gap between the downstream face of the gate and the downstream wall of the gate chamber;

A $=$ cross-sectional area of the conduit at the section of downstream control [Fig. 1(a)];

= area of the horizontal projection of the top seal;

= ratio of the flow passages downstream from the gate to the crosssectional area of the conduit (Eq. 6);

$=$ ratio of the cross-sectional areas of the contracted jet issuing underneath the gate to that of the conduit (Eq. 3); 


$$
\begin{aligned}
& \mathrm{B} \quad=\text { width of the gate (Fig. 10); } \\
& \text { b = clear width of the conduit at the gate section (Fig. 10); } \\
& \mathrm{C}, \mathrm{C}_{1}, \mathrm{C}_{2}=\text { discharge coefficients pertinent to the flow over the top of the gate } \\
& \text { (Eqs. 4, 24, } 27 \text { and 28); } \\
& \mathrm{C}_{0} \quad=\text { discharge coefficient for maximum gate opening (Eq. 14); } \\
& \mathrm{C}_{\mathrm{C}} \quad=\text { coefficient of contraction (Eq. 3); } \\
& \mathrm{C}_{\mathrm{d}} \quad=\text { discharge coefficient (Eqs. } 17 \text { and 23); } \\
& \mathrm{C}_{\mathrm{e}} \quad=\text { loss coefficient for entrance head-loss (Eq. 1); } \\
& \mathrm{C}_{\mathrm{L}} \quad=\text { loss coefficient (Eqs. } 12 \text { and 13); } \\
& \text { D = diameter of the circular conduit; } \\
& \text { d = gate thickness (Figs. } 6 \text { and 10); } \\
& \text { d' = thickness of the skinplate (Fig. 10); } \\
& \text { e } \quad=\text { projection of the skinplate (Fig. 10); } \\
& \mathrm{e}^{*} \quad=\text { total height of the gate lip (Fig. 10); } \\
& \mathrm{F} \quad=\text { forces due to pressure (Eq. 7); } \\
& \mathrm{F}_{\mathrm{S}} \quad \text { = force due to boundary shear (Eq. 9); } \\
& \text { f } \quad=\text { Darcy-Weisbach resistance factor for the conduit; } \\
& \text { g = gravitational acceleration; } \\
& \mathrm{H} \quad=\text { total head in the reservoir (Fig. 1); } \\
& \mathrm{H}_{\mathrm{e}} \quad \text { = entrance head-loss (Fig. 1); } \\
& \Delta \mathrm{H} \quad=\text { head differential between reservoir and section of downstream } \\
& \mathrm{h}_{\mathrm{i}} \quad=\text { piezometric head at a point on the gate bottom (Fig. 6); } \\
& \mathrm{h}_{1} \quad=\text { piezometric head in section (1), downstream from the standing } \\
& \mathrm{h}_{\mathrm{c}} \quad=\text { piezometric head in the section of downstream control [Fig. 1(a)]; } \\
& \mathrm{h}_{\mathrm{T}} \quad=\text { piezometric head on the top surface of the gate; } \\
& \mathrm{K} \text { = factor, compensating for departure from hydrostatic pressure dis- } \\
& \text { tribution (Eq. 11); } \\
& \mathrm{L}_{1} \quad=\text { length of the standing eddy downstream from the gate (Fig. 1a); }
\end{aligned}
$$


$\mathrm{L}_{2} \quad=$ length from section (1) to the control section (c), (Fig. 1a);

$\mathrm{V}=$ parameter for the average wetted perimeter in the reach between sections (0) and (1), (Eq. 8);

? = downpull resulting from the difference between the pressures acting on the top and bottom surfaces of the gate;

? $=$ downpull resulting from the pressure differential acting on the horizontal protrusions of the gate;

$\mathrm{j}_{\mathrm{i}} \quad=$ pressure intensity at a point on the gate bottom (Fig. 6);

$\Delta \mathrm{p}=$ difference between the pressure intensity of the air downstream from the gate and the atmospheric pressure at the reservoir, for the condition of free efflux;

$2=$ total rate of flow at gate opening $\mathrm{y}$;

$2_{\max }=$ total rate of flow at maximum gate opening;

$Q^{\prime} \quad=$ rate of flow released underneath the gate;

Q" $\quad=$ rate of flow released from the gate chamber through $\mathrm{A}_{2}$;

$\mathrm{R} \quad=$ hydraulic radius;

$R=$ Reynolds number of the flow $\left(R=2 \mathrm{dV}_{\mathrm{j}} / \nu\right)$;

$r \quad=$ radius of curvature for the rounding of the gate lip (Fig. 10);

$\mathrm{t} \quad$ = time;

$\mathrm{V} \quad=$ mean velocity;

$\mathrm{V}_{\mathrm{j}} \quad=$ velocity in the contracted jet issuing from underneath the gate;

$\mathrm{v} \quad=$ velocity;

y = gate opening (Fig. 1);

$\mathrm{y}_{0} \quad=$ conduit height immediately upstream from the gate;

$\mathrm{y}_{2}=$ vertical distance from the datum to the contracted section of the jet issuing from above the gate;

$\alpha_{1}, \beta_{1}=$ factors, compensating for the use of the mean velocity in section (1), (Eqs. 7 and 12);

$\gamma \quad=$ specific weight of water;

$\zeta \quad=$ factor, compensating for the departure from hydrostatic pressure distribution (Eq. 7);

$\theta=$ angle of inclination of the bottom surface of the gate;

${ }_{\mathrm{B}} \mathrm{B} \quad=$ dimensionless term for the piezometric head at a point of the bottom surface of the gate (Eq. 29 and Fig. 6); 


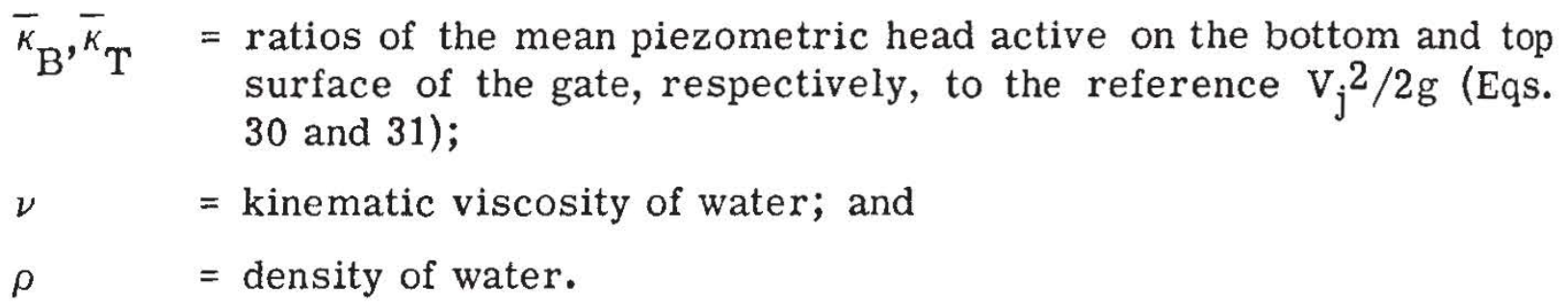

\section{APPENDIX II.-BIBLIOGRAPHY ON HIGH-HEAD GATES}

\section{A. Hydrodynamic Forces.}

1. "Report on Hiwassee Emergency Sluice Gate Studies," Tennessee Valley Authority, April 1939.

2. Warnock, J. E., and Pound, H. J., "Coaster Gate and Handling Equipment for River Outlet Conduits in Shasta Dam," Transactions, ASME, Vol. 68, No. 3, April 1946, p. 199.

3. "Comparison of the Hydraulic Forces Acting on the Outlet Coaster GateShasta Dam," Bureau of Recl. Hydr. Lab. Rep. No. Hyd-233, Denver, Oct. 1948.

4. Cronin, J. D., and Hansen, W., "An Experimental Study of the Hydraulic Downpull on a Coaster Gate," Jour. Inst. of Engineers, Australia, July/ Aug. 1949.

5. "Spillway and Outlet Works East Branch Reservoir," Waterways Exp. Station, Techn. Mem. No. 2-325, Vicksburg, July 1951.

6. "Hydraulic Laboratory Practice," Bureau of Recl. Eng. Monogr. No. 18, Denver, March 1953, p. 77.

7. "Slide Gate Tests Norfolk Dam," Waterways Exp. Station, Techn. Mem. No. 2-389, Vicksburg, July 1954.

8. Khalturina, N. W., "Pressure and Flow Conditions at a High-Head Gate Located Within the Conduit," Gidrotekhnicheskoe Stoitel'stvo (USSR), No. 7,1954 .

9. Pontow, K. H., “Abfluss und dynamische Kräfte bei unterströmten Schützen," Dissert. T. H. Karlsruhe, 1954.

10. Douma, H., "Hydraulic Design Criteria for Reservoir Outlets," Proc. Sixth Congr. IAHR, The Hague, 1955.

11. Uppal, H. L., and Singh, J., "Studies in the Hydraulic Downpull on the Emergency Gate of the River Outlet of Bhakra Dam with the Help of Models," Proc. Sixth Congr. IAHR, The Hague, 1955.

12. "Outlet Works and Spillway for Garrison Dam," Waterways Exp. Station, Techn. Mem. No. 2-431, Vicksburg, March 1956.

13. Martin, H. M., and Ball, J. W., "Hoover Dam Intake Gates Altered for Emergency Closure," Power, April 1956.

14. Simmons, W. P., and Colgate, D., "Model Studies of Hydraulic Downpull Forces that act on the Palisades-Type Regulating Slide Gate and the Glendo Fixed Wheel Gate," Bureau of Recl. Hydr. Lab. Rep. No. Hyd-421, Denver, Feb. 1957. 
15. "Hydraulic Downpull on Emergency Closure Gate," Eagle Gorge Tunnel Model, Bonneville Hyd. Lab. Memo. Rep. 5-1, Sept. 1957.

16. Naudascher, E., "Abflussmenge und dynamische Kräfte bei Tiefschützen," Der Bauingenieur, Vol. 32, No. 11, 1957, p. 428 (Discharge and Hydrodynamic Forces at Submersible Gates, transl. on file at WES).

17. Führböter, A., "Modellversuche für Talsperrentiefschütze," Mitt. Hannover. Versuchsanst. Grundbau u. Wasserbau H. 13, 1958.

18. Naudascher E., "Berechnung der dynamischen Kräfte bei Tiefschützen," Der Stahlbau, Vol. 28, No. 3, 1959, p. 57. (Computation of Dynamic Forces on High-Head Gates, transl. on file at WES).

19. Guyton, B., “Field Investigations of Spillways and Outlet Works," Transactions, ASCE, Vol. 124, 1959, p. 491.

20. Simmons, W. P., "Air Model Studies of Hydraulic Downpull on Large Gates," Proc. ASCE, Vol. 83, No. Hy 1, Jan. 1959.

21. Murphy, T. E., "Spillway and Outlet Works, Fort Randall Dam, Missouri River, South Dakota," Waterways Exp. Station, Tech. Rep. No. 2-528, Vicksburg, Oct. 1959.

22. Colgate, D., "Hydraulic Downpull Forces on High-Head Gates," Proc., ASCE, Vol. 85, No. Hy 11, Nov. 1959.

23. Nelson, M. E., Johnson, H. J., and Fidelman, S., "Lifting Forces on Lock Gates," Proc., Eighth Congr. IAHR, Montreal, 1959, A-13.

24. Bryce, J. B., and Foulds, D. M., "Vertical Hydraulic Forces on WaterControlling Gages," Proc., Eighth Congr. IAHR, Montreal, 1959, A-26.

25. Cox, R. G., Pickett, E. B., and Simmons Jr., W. P., Discussion of "Hydraulic Downpull Forces on High Head Gates" by Colgate, D., Proc., ASCE, Vol. 86, No. Hy5, May 1960.

26. Simmons, W. P., "Hydraulic Model Studies of the Island Bend Control Gate, Snowy Mountains Hydroelectric Authority, Australia," Bureau of Recl. Hydr. Lab. Rep. No. Hyd-462, Denver, April 1960.

27. Bucci, D. R. and Murphy, T. E., "Outlet Works, Oahe Dam, Missouri River, South Dakota," Waterways Exp. Station, Techn. Rep. No. 2-557, Vicksburg, Sept, 1960.

28. Uppal, H. L., "Investigations on Hydraulic Downpull Forces on Emergency Gate Under High Heads with the Help of Models," Jour. Central Board Irrig. and Power, India, Vol. 18, No. 4, April 1961, p. 315.

29. Kobus, H. E., "Effect of Lip Shape Upon Hydraulic Forces on High-Head Gates," M.S. Thesis, Univ. Iowa, 1963.

30. Rao, R. P. R., "Effect of Gate and Conduit Geometry Upon the Hydrodynamic Forces Acting on High-Head Gates," M.S. Thesis, Univ. Iowa, 1963.

\section{B. Vibration.}

1. Müller, O., "Schwingungsuntersuchungen an unterströmten Wehren," Mitt. Preuss. Versuchsanst. Wasserbau u. Schiffbau No. 13, 1933.

2. Müller, O., "Schwingungsuntersuchungen an einem unterströmten Wehrmodell," Mitt. Preuss. Versuchsanst. Wasserbau u. Schiffbau No. 31, 1937.

3. Fomitchev, M. C., "Pulsation of Dynamic Pressure Below a High-Head Gate," Gidrotekhnicheskoe Stroitel'stvo (USSR) No. 11, 1951. 
4. "Vibration, Pressure and Air-Demand Tests in Flood-Control Sluice, Pine Flat Dam," Waterways Exp. Station, Misc. Pap. No. 2-75, Vicksburg, Feb. 1954.

5. "Slide Gate Tests Norfolk Dam," Waterways Exp. Station, Techn. Mem. No. 2-389, Vicksburg, July 1954.

6. "Model Gate Vibration and Downpull Measuring Apparatus," Waterways Exp. Station. Misc. Paper No. 5-87, Vicksburg, July 1954.

7. Petrikat, K., "Schwingungsuntersuchungen an Stahlwasserbauten," Der Stahlbau, Vol. 24, No. 9 and 12, 1955.

8. Abelev, A. S., "The Basic Problems in Determining the Vibration of Gates in Hydraulic Structures," Izvestia Vses. Nauchno Issled. Inst. Gidrotekhn., Leningrad, Vol. 54, 1955.

9. "Outlet Works and Spillway for Garrison Dam," Waterways Exp. Station, Techn. Mem. No. 2-431, Vicksburg, March 1956.

10. "Vibration and Pressure-Cell Tests Flood Control Intake Gates, Fort Randall Dam," Waterways Exp. Station, Techn. Rep. No. 2-435, Vicksburg, June 1956.

11. Petrikat, K., "Vibration Tests on Weirs and Bottom Gates," Water Power, May 1958, p. 190.

12. Abelev, A. S., "Investigation of the Fluctuations in the Hydrodynamic Load for the Purpose of Calculating the Vibration in Plane High-Head Closing Devices," Izvestia Vses, Nauchno Issled. Inst. Gidrotekhn., Leningrad, Vol. 58, 1958, p. 26.

13. Abelev, A. S., " Investigation of the Total Pulsating Hydrodynamic Load Acting on Bottom Outlet Sliding Gates and its Scale Modelling," Proc., Eighth Congr. IAHR, Montreal, 1959, A-10.

14. Pickett, E. B., "Hydraulic Prototype Tests of Tainter Valve, McNary Lock," Waterways Exp. Station, Techn. Rep. No. 2-552, Vicksburg, June 1960.

15. Campbell, F. B., "Vibration Problems in Hydraulic Structures," Proc. ASCE, Vol. 87, No. Hy 2, March 1961, and Discussion, Nov. 1961.

16. Abelev, A. S., "Maximum and Mean Hydrodynamic Load Acting on LeafType, Butterfly-Type, and Segment-Type High-Head Gates," Izvestia Vses. Nauchno. Issled. Inst. Gidrotekhn., Leningrad, Vol.67, 1961, p. 29 and 39.

17. Abelev, A. S., "Determination of the Total Pulsating Hydrodynamic Load, Acting upon Leaf-Type High-Head Gates," Izvestia Vses. Nauchno. Issled. Inst. Gidrotekhn., Leningrad, Vol。68, 1961, p. 33.

18. Abelev, A. S., "Relation Between the Pressure Pulsation in Particular Points and the Pulsating Hydrodynamic Load Acting upon High-Head Gates," Izvestia Vses. Nauchno. Issled. Inst. Gidrotekhn., Leningrad, Vol. 69, 1961.

19. Vigander, S., “A Study of Flow Through Abrupt Two-Dimensional Expansion," Progress Report IV: Effect of Gate Oscillation, Studies in Engr. Mech. Rep. No. 7, University of Kansas, 1962.

20. Perkins, J. A., "Model Investigations of the Vibration of a Vertical-Lift Sluice Gate," Proc., Tenth Congr. IAHR, London, 1963.

21. Naudascher, E., "On the Role of Eddies in Flow-Induced Vibrations," Proc., Tenth Congr. IAHR, London, 1963. 


\section{Cavitation.}

1. Thomas, H. A., and Schuleen, S. P., "Cavitation in Outlet Conduits of High Dams," Transactions, ASCE, Vol. 107, 1942, p. 421.

2. "Cavitation in Hydraulic Structures," A Symposium, Transactions, ASCE, Vol. 112, 1947, p. 97.

3. Spengo, A., "Cavitation and Pressure Distribution at Gate Slots," M.S. Theses, Univ. Iowa, 1949.

4. "Cavitation in Hydrodynamics," Proc. Natl. Physics Lab. Symposium, London, 1956.

5. "Report on Erosion of Concrete and Installation of Steel Liner Plates in Outlet Channels 1 through 6, Lucky Peak Dam," U. S. Army Eng., Walla Walla, Wash., Feb. 1957.

6. Joglekar, D. V., and Damle, P. M., "Cavitation Free Sluice Outlet Design," proc., Seventh Congr. IAHR, Lisbon, 1957.

7. Ball, J. W., "Hydraulic Characteristics of Gate Slots," Proc., ASCE, Vol. 85 , No. Hy 10, Oct. 1959, (see also references E. 27 and 28).

8. Duport, T. P., and Bertrand, T. P., "Choix des conditions aux limites dans les essais de cavitation de vannes," Proc., Eighth Congr. IAHR, Montreal, 1959, A-21.

9. Eisenberg, P., "Mechanics of Cavitation," Handbook of Fluid Dynamics, Sect. 12, McGraw-Hill, 1961.

10. Rao. G. N.S., and Thiruvengadam, A., "Prediction of Cavitation Damage," Proc. ASCE, Vol. 87, No. Hy 5, 1961.

11. Brown, F. R., "Cavitation in Hydraulic Structures," Proc. ASCE, Vol. 89, No. Hy 1, Jan. 1963, p. 99.

\section{Air Entrainment.}

1. Lane, E. W., and Kindsvater, C. E., "The Hydraulic Jump in Enclosed Conduits," Eng. News-Record, Vol. 121, Dec. 1938, p. 815.

2. Kalinske, A. A., and Robertson, J. M., "Closed Conduit Flow," Transactions, ASCE, Vol. 108, 1943, p. 1435.

3. Kalinske, A. A., and Bliss, P. H., "Removal of Air from Pipe Lines by Flowing Water," Civil Engineering, Vol. 13, No. 10, 1943.

4. Campbell, F. B., and Guyton, B., "Air Demand in Gated Outlet Works," Minnesota Intern. Hydr. Convention, Minneapolis, 1953.

5. Dettmers, D., "Beitrag zur Frage der Belüftung von Tiefschützen," Mitt. Hannover. Versuchsanst. Grundbau u. Wasserbau, H. 4, 1953.

6. "Pressure and Air-Demand Tests in Flood-Control Conduit, Denison Dam," Waterways Exp. Stat. Misc. Pap. No. 2-31, Vicksburg, April 1953.

7. Delara, G. C., "Degazage naturel dans les puits inclines reliant les adductions secondaires aux galeries en charge," Proc., Sixth Congr. IAHR, The Hague, 1955, C. 19.

8. Fasso, C. A., "Experimental Research on Air Entrainment in Gated Outlet Works," Proc., Sixth Congr. IAHR, The Hague, 1955, C. 26.

9. Haindl, $K_{\text {. }}$, and Sotornik, V., "Quantity of Air Drawn into a Conduit by the Hydraulic Jump and its Measurement by Gamma-Radiation," Proc., Seventh Congr. IAHR, Lisbon, 1957, D. 31.

10. Haindl, K., "Hydraulic Jump in Closed Conduits, Proc., Seventh Congr. IAHR, Lisbon, 1957, D. 32. 
11. Ghetti, A., "Hydraulic Investigation of Closure Devices for Bottom Outlets of Reservoirs with the Aid of Experiments," (Ital.), L'Energia Elettrica, No. 9, 1959, p. 801.

12. Wunderlich, W., "Beitrag zur Belüftung des Abflusses in Tiefauslässen," Dissert. T. H. Karlsruhe, 1961.

13. Uppal, H. L., and Paul, T. C., "Jet Flow Gates and Air Requirement," Jour. Central Board Irrig. and Power, India, Vol. 18, No. 12, Dec. 1961, p. 1131 .

14. Goljevšček, M. “Dimensioning of the Ventilation of Outlet Works in Dams," Vodogradbeni Laboratorij v Ljubljani, No. 3, 1961, p. 23.

\section{E. Related Hydraulic Problems.}

1. "Hydraulic Design Criteria," U. S. Army Engineer, Waterways Exp. Station, Vicksburg.

2. Warnock, J. E., and Dewey, H. G., "Hydraulic Structures, Model-Prototype Conformity," and discussion, Transactions, ASCE, Vol. 109, 1944, p. 3.

3. "Model Studies of Conduits and Stilling Basin Bull Shoals Dam," (on Gate Slots), Waterways Exp. Station, Techn. Mem. No. 2-234, Vicksburg, June 1947.

4. Gentilini, B., “Flow of Water Under a Bottom Gate," La Houille Blanche, Liste de tirage, 2-1947.

5. Smetana, J., “Ecoulement de i'eau au-dessous d'une vanne et forme rationnelle de la surface d'appui de la vanne," La Houille Blanche. No. 1, Jan. 1948, p. 41 and 126.

6. Abelev, A. S., "Discharge Characteristics of Leaf Gates for Outlet Conduits," Izvestia Vses. Nauchno Issled. Inst. Gidrotekhn., Leningrad, Vol. 42,1950 .

7. Weber, W. G., "Operating Experiences with High-Head Gates and Valves," Proc., 6th Meeting, Natl. Conf. Indust. Hydr., Vol. IV, 1950, p. 216.

8. Liscovec, L. A., "A Study of the Inlet Shape of Reservoir Outlets," Transactions Fourth Congr. on Large Dams, Vol. II, New Delhi, 1951.

9. Case, W. C., "Hydraulic Laboratory Tests of Seals for High-Head Coaster and Fixed-Wheel Structural Gates," Waterways Exp. Station, Hydr. Lab. Rep. No. Hyd-311, July 1951.

10. "Hydraulic Model Studies of the 7-Ft-6-Inch by 9-Ft-0-Inch Palisades Regulating Slide Gate, Palisades Project, Idaho," Bureau of Recl., Hyd. Lab. Rep. No. Hyd-387, Denver, June 1954.

11. Thomas, C. W., "Discharge Coefficients for Gates and Valves as Determined by Field and Laboratory Studies," ASCE Proc. Separate, No. 746, July 1955.

12. "Flood Control Conduits for Detroit Dam," Bonneville Hyd. Lab., Rep. No. 45-1, June 1955 .

13. "Laboratory Tests on Hydraulic Models of Conduit Gate Structures and Transitions," U. S. Army Eng., St. Paul Distr. Rep. No. 61, Index CE-J, Nov. 1955.

14. Mura, Y., and Araki, M., "Some Hydraulic Problems of Outlet Conduits," Proc., Sixth Congr. IAHR, The Hague, 1955, C. 5.

15. Wickert, G., "Folgerungen aus der Hydraulik für Tiefschütze," Der Bauingenieur, Vol. 31, No. 3, 1956. 
16. Kovalev, F. Ya., "The Flow Capacity of a Bottom-Discharge Flood Gate," (USSR) Sb. Stud. Nauchn. Rabot. Belorussk. Politkhn., No. 3, 1957, p. 92.

17. "Laboratory Investigations of Outlet Works," Waterways Exp. Station, Rep. No. 2-204, Vicksburg, March 1957.

18. Simmons, W. P., "Air and Hydraulic Model Studies of the Effect of Moving the Slots Upstream in a Slide Gate, and of Reducing the Slot Size Near the Floor," Bureau of Recl., Hyd. Lab. Rep. No. Hyd-432, Denver, June 1957.

19. "Repair of Low Level Outlets, Detroit Dam," Portland Distr. Corps of Engineers, Nov. 1957.

20. Megard, J., "Quelques problèmes posés par les reniflards dans les amenées d'eau," Proc., Seventh Congr. IAHR, Lisbon, 1957, C. 24.

21. "Field Investigations of Spillways and Outlet Works," Waterways Exp. Station, Misc. Pap. No. 2-234, Vicksburg, Aug. 1957.

22. "Model Prototype Correlation, Chief Joseph Tests," Ice Harbor Powerhouse Intake Gate Model, Bonneville Hyd. Lab., Memo. Rep. 1-1, Feb. 1958.

23. "Considerations of Various Factors Entering into the Evaluation of Intake Losses from Experimental Measurements," Waterways Exp. Station, Rep. No. 2-320, Vicksburg, Feb. 1959.

24. "Outlet Works for Abiquin Dam, Rio Chama, New Mexico, Hydr. Model Investigations," (Transactions from Rectangular to Circular Section, etc.), Waterways Exp. Station, Techn. Rep. No. 2-513, Vicksburg, June 1959.

25. Ball, J. W., "Hydraulic Characteristics of Gate Slots," Proc., ASCE, Vol. 85, No. Hy 10, Oct. 1959. (See also references E. 27 and 28).

26. Thomas, C. W., "Hydraulic Performance of 96-inch Regulating Gates in Closed Conduits," Proc., Eighth Congr. IAHR, Montreal, 1959, A 8.

27. Thiruvengadam, A., McPherson, M. B., and Kohler, W. H., Discussion of "Hydraulic Characteristics of Gate Slots" by Ball, J. W., Proc. ASCE, Vol. 86, No. Hy 4, April 1960.

28. Tinney, E. R., Robertson, J. M., and Bennett, H. W., Discussion of "Hydraulic Characteristics of Gate Slots" by Ball, J. W., Proc. ASCE, Vol. 86, No. Hy 5, May 1960.

29. Liscovec, L., "Research on Inlets for Pressure Conduits," Výskumny் Ustav Vodohospodarsy Práce a Studie, Bratislava, (Czech), No. 102, 1961.

30. McCaig, I. W., and Jonker, F. H., "Surges in Air Vents Adjacent to Emergency Gates," Transactions, ASCE, J. Basic Eng., Vol. 83, Series D, No. 4, Dec. 1961.

31. Wunderlich, W. , "Grundablässe an Talsperren," Die Wasserwirtschaft, Vol. 53, No. $3 / 4,1963$.

\section{F. Related Structural Problems.}

1. Dams and Control Works, U.S. Department of the Interior, Bureau of Reclamation, 1929 edit.: High-Pressure Outlets, p. 92; 1938 edit.: HighPressure Outlets, p. 177; 1954 edit.: Reservoir Outlet and Spillway Gates, p. 205.

2. Design Standards, Vol. 7, "Valves, Gates and Steel Conduits," U. S. Department of the Interior, Bureau of Reclamation.

3. Boissounault, F. L., "Estimating Data for Reservoir Gates," Transactions, ASCE, Vol. 113, 1948, p. 992.

4. Davis, C. F. (editor), Handbook of Applied Hydraulics, McGraw-Hill, 1952 , 2nd edit., p. 386-402. 
5. "Hydraulic Design, Chapter 2, Reservoir Outlet Structures," U. S. Army Eng., Eng. Manual, Civil Works Constr., Part CXVI, Feb. 1953.

6. Haase, E., "High-Head Sluice Gates," Water Power, February 1956, p. 55.

7. Skinner, S. J., "Fixed-Wheel Gates for Penstock Intakes," Transactions ASCE, Vol. 124, 1959, p. 740.

8. Rozanov, N. M., Design of Outlet Works for High Velocities and Subatmospheric Pressures, Gosenergoizdat (USSR), 1959.

9. Mosonvi, E., Wasserkraftwerke, Vol. 2, Kultura-Bibliografia, Budapest, 1959. 